\title{
चUSGS
}

science for a changing world

\section{TOTAL PETROLEUM SYSTEMS OF THE BONAPARTE GULF BASIN AREA, AUSTRALIA: JURASSIC, EARLY CRETACEOUS-MESOZOIC; KEYLING, HYLAND BAY- PERMIAN; MILLIGANS-CARBONIFEROUS, PERMIAN}

by Michele G. Bishop ${ }^{1}$

Open-File Report 99-50-P

1999

This report is preliminary and has not been reviewed for conformity with the U. S. Geological Survey editorial standards or with the North American Stratigraphic Code. Any use of trade names is for descriptive purposes only and does not imply endorsements by the U. S. government.

U. S. Department of the Interior

U. S. Geological Survey

${ }^{1}$ Consultant, Wyoming PG-783, contracted to U. S. Geological Survey, Denver, Colorado 


\section{FOREWORD}

This report was prepared as part of the World Energy Project of the U.S. Geological Survey. In this project, the world was divided into 8 regions and 937 geologic provinces, which were then ranked according to the discovered oil and gas volumes within each (Klett and others, 1997). Then, 76 "priority" provinces (exclusive of the U.S. and chosen for their high ranking) and 26 "boutique" provinces (exclusive of the U.S. and chosen for their anticipated petroleum richness or special regional economic importance) were selected for appraisal of oil and gas resources. Portions of numerous additional "boutique" provinces were eventually included. The petroleum geology of these priority and boutique provinces is described in this series of reports.

The purpose of the World Energy Project is to assess the quantities of oil, gas, and natural gas liquids that have the potential to be added to reserves within the next 30 years. These volumes either reside in undiscovered fields whose sizes exceed the stated minimumfield-size cutoff value for the assessment unit (variable, but must be at least 1 million barrels of oil equivalent) or occur as reserve growth of fields already discovered.

The total petroleum system constitutes the basic geologic unit of the oil and gas assessment. The total petroleum system includes all genetically related petroleum that occurs in shows and accumulations (discovered and undiscovered) that (1) has been generated by a pod or by closely related pods of mature source rock, and (2) exists within a limited mappable geologic space, together with the essential mappable geologic elements (reservoir, seal, and overburden rocks) that control the fundamental processes of generation, expulsion, migration, entrapment, and preservation of petroleum. The minimum petroleum system is that part of a total petroleum system encompassing discovered shows and accumulations along with the geologic space in which the various essential elements have been proved by these discoveries.

An assessment unit is a mappable part of a total petroleum system in which discovered and undiscovered fields constitute a single relatively homogenous population such that the chosen methodology of resource assessment based on estimation of the number and sizes of undiscovered fields is applicable. A total petroleum system might equate to a single assessment unit, or may be subdivided into two or more assessment units if each assessment unit is sufficiently homogeneous in terms of geology, exploration considerations, and risk to assess individually.

A graphical depiction of the elements of the total petroleum system is provided in the form of an event chart that shows the time of (1) deposition of essential rock units; (2) trap formation; (3) generation, migration, and accumulation of hydrocarbons; and (4) preservation of hydrocarbons.

A numeric code identifies each region, province, total petroleum system, and assessment unit; these codes are uniform throughout the project and will identify the same item in any of the publications. The code is as follows: 
Region, single digit

Example

3

Province, three digits to the right of region code

3162

Total Petroleum System, two digits to the right of province code

316205

Assessment unit, two digits to the right of petroleum system code

31620504

The codes for the regions and provinces are listed in Klett and others (1997).

Oil and gas reserves quoted in this report are derived from Petroconsultants' Petroleum Exploration and Production database (Petroconsultants, 1996) and other area reports from Petroconsultants, Inc., unless otherwise noted.

Fields, for the purpose of this report, include producing fields, discoveries (suspended and abandoned) and shows as defined by Petroconsultants (1996) and may consist of a single well with no production.

Figure(s) in this report that show boundaries of the total petroleum system(s), assessment units, and pods of active source rocks were compiled using geographic information system (GIS) software. Political boundaries and cartographic representations were taken, with permission, from Environmental Systems Research Institute's ArcWorld 1:3 million digital coverage (1992), have no political significance, and are displayed for general reference only. Oil and gas field centerpoints, shown on this (these) figure(s), are reproduced, with permission, from Petroconsultants, 1996.

\section{REFERENCES}

Environmental Systems Research Institute Inc., 1992, ArcWorld 1:3M digital database: Environmental Systems Research Institute, Inc. (ESRI), available from ESRI, Redlands, CA, scale: 1:3,000,000.

Klett, T.R., Ahlbrandt, T. A., Schmoker, J.W., and Dolton, G. L., 1997, Ranking of the world's oil and gas provinces by known petroleum volumes: U.S. Geological Survey Open-File Report 97-463, one CD-ROM.

Petroconsultants, 1996, Petroleum Exploration and Production Database: Petroconsultants, Inc., P.O. Box 740619, 6600 Sands Point Drive, Houston TX 77274-0619, USA or Petroconsultants, Inc., P.O. Box 152, 24 Chemin de la Mairie, 1258 Perly, Geneva, Switzerland. 


\section{ABSTRACT}

The Bonaparte Gulf Basin Province (USGS \#3910) of northern Australia contains three important hydrocarbon source-rock intervals. The oldest source-rock interval and associated reservoir rocks is the Milligans-Carboniferous, Permian petroleum system. This petroleum system is located at the southern end of Joseph Bonaparte Gulf and includes both onshore and offshore areas within a northwest to southeast trending Paleozoic rift that was initiated in the Devonian. The Milligans Formation is a Carboniferous marine shale that sources accumulations of both oil and gas in Carboniferous and Permian deltaic, marine shelf carbonate, and shallow to deep marine sandstones.

The second petroleum system in the Paleozoic rift is the Keyling, Hyland BayPermian. Source rocks include Lower Permian Keyling Formation delta-plain coals and marginal marine shales combined with Upper Permian Hyland Bay Formation prodelta shales. These source-rock intervals provide gas and condensate for fluvial, deltaic, and shallow marine sandstone reservoirs primarily within several members of the Hyland Bay Formation. The Keyling, Hyland Bay-Permian petroleum system is located in the Joseph Bonaparte Gulf, north of the Milligans-Carboniferous, Permian petroleum system, and may extend northwest under the Vulcan graben sub-basin.

The third and youngest petroleum system is the Jurassic, Early CretaceousMesozoic system that is located seaward of Joseph Bonaparte Gulf on the Australian continental shelf, and trends southwest-northeast. Source-rock intervals in the Vulcan graben sub-basin include deltaic mudstones of the Middle Jurassic Plover Formation and organic-rich marine shales of the Upper Jurassic Vulcan Formation and Lower Cretaceous Echuca Shoals Formation. These intervals produce gas, oil, and condensate that accumulates in, shallow- to deep-marine sandstone reservoirs of the Challis and Vulcan Formations of Jurassic to Cretaceous age. Organic-rich, marginal marine claystones and coals of the Plover Formation (Lower to Upper Jurassic), combined with marine claystones of the Flamingo Group and Darwin Formation (Upper Jurassic to Lower Cretaceous) comprise the source rocks for the remaining area of the system. These claystones and coals source oil, gas, and condensate accumulations in reservoirs of continental to marine sandstones of the Plover Formation and Flamingo Group.

Shales of the regionally distributed Lower Cretaceous Bathurst Island Group and intraformational shales act as seals for hydrocarbons trapped in anticlines and fault blocks, which are the major traps of the province.

Production in the Bonaparte Gulf Basin Province began in 1986 using floating production facilities, and had been limited to three offshore fields located in the Vulcan graben sub-basin. Cumulative production from these fields totaled more than 124 million barrels of oil before the facilities were removed after production fell substantially in 1995. Production began in 1998 from three offshore wells in the Zone of Cooperation through floating production facilities. After forty years of exploration, a new infrastructure of pipelines and facilities are planned to tap already discovered offshore reserves and to support additional development. 


\section{INTRODUCTION}

There are two Total Petroleum Systems (TPS) located in a Devonian failed rift, that is now the site of the Joseph Bonaparte Gulf on the northern coast of Australia (Fig. 1). These systems consist of (1) a Carboniferous marine shale source rock with Carboniferous and Permian reservoir rocks, and (2) Permian shallow marine, coal, and deltaic shale source rocks with Permian reservoir rocks. The first (MilligansCarboniferous, Permian, 391001) contains one assessment unit (Barnett, 39100101) for the purpose of estimating potential resources (Fig. 1). The second (Keyling, Hyland BayPermian, 391002) contains two assessment units (Petrel, 39100201, Vulcan, 39100202) (Fig. 1). The Petrel assessment unit is located in the Petrel sub-basin where gas discoveries have been made. The Vulcan assessment unit is located beneath the Mesozoic age petroleum system.

A third petroleum system is located on the Australian continental shelf in a basin trend perpendicular to the Devonian rift, where maximum subsidence occurred in Jurassic through Cretaceous time. This system (Jurassic, Early Cretaceous-Mesozoic, 391003) consists of Jurassic and Cretaceous organic-rich marine shales and Jurassic and Cretaceous reservoirs in one assessment unit (Malita, 39100301) (Fig. 1).

Another petroleum system, consisting of Upper Devonian carbonates or Bonaparte Formation shales, may source shows in Upper Devonian Ningbing Limestone in combination with source shales of the Milligans Formation (McConachie and others, 1996). This possible petroleum system will not be discussed as part of this report.

Twenty nine fields have been identified in the Bonaparte Gulf Basin Province by Petroconsultants (1996) since exploration began in 1959, and only three have produced oil up to 1997(Australian Geological Survey Organisation, 1998). Known reserves for the province are estimated at 3.2 billion barrels of oil equivalent (BBOE) (Klett and others, 1997). In 1998, three new offshore fields on the Australian continental shelf began production (World Oil, 1999).

\section{PROVINCE GEOLOGY}

The USGS Bonaparte Gulf Basin Province 3910 includes onshore areas of Western Australia and Northern Territory, offshore areas including the Joseph Bonaparte Gulf (divided between Western Australia and Northern Territory), waters of the Territory of Ashmore and Cartier Islands, Australian portions of the Timor Sea, the Zone of Cooperation, and waters of Indonesia and East Timor (Figs. 1 and 2). Offshore water depths are as much as $3000 \mathrm{~m}$ and the Bonaparte Basin covers an area, both onshore and offshore, of approximately $270,000 \mathrm{~km}^{2}$ (Lavering and Ozimic, 1988; Mory, 1988). The Petrel sub-basin (Bonaparte Gulf, or Southern Bonaparte Basin) (Fig. 3) consists of a Paleozoic failed rift with a present-day northwest-southeast trend, and includes both onshore and offshore areas (DPIE, 1998). The Timor Sea areas of the province consist of a southwest-northeast Mesozoic trend of two major sub-basins (Vulcan graben sub-basin and Malita graben) connected around the Flamingo and Laminaria highs by northwestsoutheast trending synclines (Fig. 3).

The province is primarily under the jurisdiction of Australia. The boundary between Western Australia and the Northern Territory divides the Joseph Bonaparte Gulf (Fig. 2). The waters of the Territory of Ashmore and Cartier Islands, Australia, angle across the northwest corner of the province. The international boundary with Indonesia 
and East Timor runs near the northern province boundary. The Zone Of Cooperation (ZOC) was formed in 1991 between Australia and Indonesia to govern exploration in an area of approximately $61,000 \mathrm{~km}^{2}$ south of the island of Timor toward the Bonaparte Gulf ending a dispute of more than a decade. The ZOC is further divided into A, B, and $\mathrm{C}$ each with different levels of control among the participating entities (Fig. 2). In February 2000 the United Nations Transitional Administration in East Timor replaced Indonesia as partner in the ZOC (Oil \& Gas Journal, 2000).

The Paleozoic failed rift, initiated in the Devonian, trends northwest-southeast and includes the geologic provinces of the Kimberley Block to the west, and portions of the Londonderry high, the Plover-Lacrosse terrace, and Berkley platform, which are all faulted features bordering the Kimberley Block (Fig. 3). The basin continues northeast to the Darwin shelf and Money Shoal basin near Bathurst Island. The Carlton basin lies primarily onshore to the south (Fig. 3). The Paleozoic rift basin is intersected and overprinted by a basin trend that developed during the Mesozoic.

Major geologic structural features of the Mesozoic trend include the Yampi shelf, Londonderry high, Vulcan graben sub-basin, Ashmore platform, Sahul trough or syncline, Sahul platform, Flamingo high and trough or syncline, Darwin shelf or platform, Malita graben, Calder graben and northern portions of the Goulburn graben (Figs. 3 and 4) (Edwards and others, 1997; Gunn, 1988a; Hocking and others, 1994; Mc Lennan and others, 1990). The Malita graben extends northeast between the eastern portion of the Sahul platform and the Darwin platform and Lynedoch Bank fault system and blends with the Calder graben of similar trend. The Malita graben ends at the Lynedoch Bank fault where the Goulburn graben begins (DPIE, 1998). Underlying the Goulburn graben in the easternmost portion of the province is another Paleozoic rift trending northwest-southeast. The Mesozoic portion of the Goulburn graben, the Money Shoal basin, is a sag basin that unconformably overlies and progressively oversteps the edges of the Paleozoic rift-faulted basin east of the province, the Arafura basin (DPIE, 1998). Numerous bitumen (tar) strandings on the shores of the northern coasts of the islands and peninsulas of Australia are reported in the Money Shoal Basin Province (Fig. 1) (Martin and Cawley, 1991; Summons and others, 1993; DPIE, 1998).

\section{PALEOZOIC}

The Paleozoic rift basin contains two petroleum systems, one that formed during Devonian to Early Carboniferous development of the rift (Milligans-Carboniferous, Permian, 391001), and one that formed later in the Late Carbonifeous to Permian stage (Keyling, Hyland Bay-Permian, 391002). The Paleozoic rift opened in a pivotal style from a pole at the southern end of the province and separated the Kimberley Block from the Sturt Block and Darwin shelf (Gunn, 1988a). Extension of $80 \mathrm{~km}$ with little displacement of continental crust by an axial intrusion occurred at the southern end (Fig. 4, G-H) (Gunn, 1988a). Extension at the northern end separated the rift margins by more than $250 \mathrm{~km}$; the axial intrusion was split and oceanic crust more than $100 \mathrm{~km}$ wide was formed (Fig. 4, C-D and E-F). Gravity lows, indicating areas of thick sediments, alternate from the west side of the basin to the east and back again (Gunn, 1988a; O'Brien, 1993). Possible transform/transfer and bounding faults were mapped by Gunn (1988a). The alternating thick sediments and the mapped faults both suggest a rifting style of connected, alternating, asymmetrical half grabens (Bosworth, 1985). 
McConachie and others (1996) also describe transform faults that divide the rift into compartments (Barnett, Tern, and Curlew) that influenced deposition, maturation, and migration.

In the Paleozoic rift basin, Devonian to Tertiary sedimentary rocks reach a total thickness in excess of $17 \mathrm{~km}$ (Mory, 1988). These strata comprise the MilligansCarboniferous, Permian (391001) and the Keyling, Hyland Bay-Permian (391002) petroleum systems (Fig. 5). In the Petrel sub-basin, strata overlie oceanic crust and thicken northward from onshore to where the Paleozoic Petrel sub-basin is intersected by the Mesozoic Malita graben (Fig. 4, C-D) (DPIE, 1998). Paleozoic strata thin gradually to the northeast onto the Darwin shelf (Fig. 4, E-F) (Miyazaki, 1997). An extensive period of non-deposition or erosion occurred between Cambrian and Devonian times, and Devonian salt deposits directly overlie basement rocks, which consist of Cambrian volcanics and sandstones (Edwards and others, 1997; Gunn, 1988a; McLennan and others, 1990). Deposition of evaporites and rift-fill sediments proceeded marine to nearshore clastic and carbonate sedimentation that continued through the Carboniferous and Permian (Fig. 5). Upper Devonian carbonate reefs developed on structurally high fault blocks. Other syn-rift deposits include shallow marine clastics, shelf carbonates and clastics, and basinal clastics. During the Carboniferous through Early Triassic sag phase of the Paleozoic rift basin development, shallow marine, deltaic, and coastal plain sediments were deposited. A tectonic compressional event during Middle Triassic and Early Jurassic time uplifted and eroded the flanks of the Paleozoic rift basin and produced faulted inverted structures (DPIE, 1998). Fault-drape anticlines and monoclines developed at this time primarily in the southwestern and central portions of the Paleozoic basin. As tectonic activity focused on the outer Mesozoic basin trend, JurassicCretaceous deposition in the Paleozoic rift basin consisted of fluvial, deltaic, and shallow marine sands (Gunn, 1988b). Paleozoic structural trends remain prominent in the basin and salt diapirs are scattered throughout (Fig 3). The salt contains Middle to Late Devonian palynomorphs suggesting either a pre-rift, Late Ordovician to Early Silurian age or a syn-rift, Middle Devonian age for the salt (DPIE, 1998; Gunn, 1988b; Jefferies, 1988; Warris, 1993).

The presence of the Keyling, Hyland Bay-Permian system beneath the Vulcan graben is implied by evidence of the presence of the Paleozoic rift. This northward extension of the rift is suggested by salt diapirs that occur in the Vulcan graben sub-basin sourced by salt from the same Devonian section that is the origin of diapirs in the Petrel sub-basin (DPIE, 1998; Gunn, 1988a,b; Jefferies, 1988; Warris, 1993).

\section{MESOZOIC}

Tectonic activity and subsidence shifted in the Mesozoic to the northwest margin of the Bonaparte Gulf Basin Province resulting from continental breakup along the entire northern and western margins of Australia and the formation of faulted platforms of continental crust and abyssal plains of oceanic crust. The Mesozoic trend includes the Vulcan graben sub-basin with tilted fault blocks and grabens, confined to the east by the Permo-Triassic Londonderry high and to the west by the Ashmore platform, and the Malita graben sub-basin, bounded to the north by the Sahul platform and to the south by the Darwin shelf (Fig. 3). Sedimentary rocks are as much as $10 \mathrm{~km}$ thick in the subbasins and $4 \mathrm{~km}$ thick over the highs (Fig. 4). Deposition of a thick sequence of shallow 
marine and fluvial deltaic clastics during Triassic to Middle Jurassic in the Vulcan graben sub-basin consisted of $2.5 \mathrm{~km}$ of deltaic sands, deep marine muds, and deep-water fans during Late Jurassic-Early Cretaceous time (DPIE, 1998; Pattillo and Nicholls, 1990; Baxter and others, 1999). Subsidence of the Malita sub-basin occurred primarily during the Cretaceous. Jurassic sediments are thin or absent on the Ashmore platform (DPIE, 1998). The sub-basins are offset and connected by the Sahul and Flamingo synclines or troughs that trend roughly north-south (Fig. 3). These features may be related to Paleozoic rifting in as much as they originated during the Permian and are aligned with the Paleozoic rift trend (DPIE, 1998; Robinson and others, 1994). Fluvial deposits to deep-water fans and restricted marine shales accumulated in the Sahul syncline from Late Jurassic to Early Cretaceous time, when sediment supply was greater than subsidence and the syncline was filled and no longer a topographic low (Robinson and others, 1994). These sub-basin strata are overlain by $1.5-3 \mathrm{~km}$ of passive margin ramp deposits of Early Cretaceous to Tertiary age consisting of fine-grained clastics and carbonates forming the modern continental shelf (Fig. 5) (DPIE, 1998). Salt diapirs of Late Ordovician to Early Silurian or Middle Devonian age are also present in the Vulcan graben sub-basin (Fig. 4) (Pattillo and Nicholls, 1990; Woods, 1994; DPIE, 1998). Structural style differs in the Vulcan graben sub-basin across the Paqualin Transfer Zone (Smith and Sutherland, 1991; Woods, 1994). This difference, and the occurrence of salt along the transfer zone, may be due to the underlying presence of the Paleozoic rift. The Paqualin Transfer Zone may be a structural element of the Paleozoic rift, perhaps the rift margin.

Collision of the Australian and Asian plates during the Tertiary Timorese orogeny resulted in fault rejuvenation and compression of the outer Timor Sea area from Miocene to Holocene (Mildren and others, 1994; Nelson, 1993). Subsequent strong east-trending compressional faulting has modified some of the earlier Mesozoic structural grain (Mildren and others, 1994; Nelson, 1993).

\section{PALEOZOIC PETROLEUM SYSTEMS \\ MILLIGANS-CARBONIFEROUS, PERMIAN 391001 \\ Petroleum Occurrence}

Onshore exploration in the Bonaparte Gulf Basin Province began in 1959 with the drilling of Spirit Hill-1 (Fig. 6), which showed residual oil in the Carboniferous Milligans Formation. Bonaparte-1 and -2, were drilled in 1963, followed by Kulshill-1 and -2, and Moyle-1, in 1965. Discoveries thus far have been concentrated onshore in fault blocks and anticlines and offshore on fault block highs, flanks of salt diapirs, and drape anticlines.

Onshore in the south, most of the discoveries have been gas with some associated oil, whereas, just to the north a band of offshore and onshore oil discoveries occurs. At Turtle-2 (Fig. 6), 34.5 $5^{\circ}$ API oil was recovered from the Milligans Formation and $36^{\circ}$ API oil from the overlying Lower Carboniferous Tanmurra Formation (Fig. 5) (McConachie and others, 1996). The Upper Carboniferous Kuriyippi Formation yielded $14.3^{\circ}$ API oil in the Turtle-2 well and 38.6 ${ }^{\circ}$ API oil in Barnett-2 (Fig. 6) (DPIE, 1998).

\section{Source Rock}

The Milligans-Carboniferous, Permian TPS 391001 contains one source rock complex and one assessment unit, the Barnett assessment unit 39100101 (Fig. 6). The Carboniferous Milligans Formation is the source rock for sandstone reservoirs in the 
Kuriyippi Formation, Milligans Formation, and Langfield Group, and the probable source of some of the oil in the underlying Devonian carbonate reservoirs (Figs. 5 and 7) (DPIE, 1998; McConachie and others, 1996). This petroleum system was referred to as the Larapintine/Gondwanan Transitional system of McConachie and others (1996) and Larapintine 4 of Edwards and others (1997).

The Milligans Formation of the Weaber Group consists of 200 to more than 2000 $\mathrm{m}$ of offshore-to-basinal shale containing submarine fan deposits that are proven reservoirs. The Milligans Formation unconformably overlies marine carbonates and shales of the Keep River Group (Bonaparte) and in turn is overlain disconformably by the transgressive Tanmurra Formation (Fig. 5) (Lavering and Ozimic, 1988). The formation thickens rapidly from the shelf into the basin indicating a high rate of basin subsidence during Early Carboniferous time (Visean) (Fig. 4, G-H) (McConachie and others, 1996). Biomarkers of marine (sapropelic) algal and bacterial lipids mixed with terrestrial material from anoxic clay-rich sediments, a total organic carbon (TOC) content range of 0.1 to $2.0 \mathrm{wt} \%$, hydrocarbon index (HI) from 10-100 $\mathrm{mg}$ hydrocarbon (HC)/g TOC, Sulfur $<0.3 \%$, pristane/phytane $(\mathrm{Pr} / \mathrm{Ph}) 1.1-2.3$, and vitrinite reflectance in oil $\left(\mathrm{R}_{\mathrm{o}}\right)$ $0.95 \%$ characterize the Milligans Formation source rocks (Jefferies, 1988). It is considered to be the source rock for accumulations in the onshore and offshore at Turtle and Barnett fields, at Waggon Creek-1, Keep River-1, Weaber-1 and 2A, Bonaparte-2, Garimala, and perhaps at Kulshill and Lacrosse (Fig. 6) (DPIE, 1998; Edwards and others, 1997). It possibly also contributes to Ningbing, but analysis of oil shows at Ningbing-1 indicate a carbonate marine source rock rather than the clastic marine source rock of the Milligans Formation; a petroleum system based on carbonate source rocks will not be addressed in this report (McConachie and others, 1996). The area of mature source rock in the Milligans Formation extends onshore south of Waggon Creek-1 and Weaber-1 offshore to approximately lat $14^{\circ}$ S. (Fig. 6) (DPIE, 1998) and is interpreted, from multiple migration and biodegradation events, to have remained in the oil generating window from Carboniferous/Permian time (McConachie and others, 1996; DPIE, 1998) to recent times (Fig. 7) (Durrant and others, 1990).

\section{Reservoir Rock}

Reefs of the Devonian (Fammenian) Ningbing Formation (Group in Warris, 1993) have porosities as much as $20 \%$ and numerous oil shows (Warris, 1993). The Ningbing reefs and the Tournaisian Langfield Group are equivalents onshore of clastic turbidity current deposits and shales of the Bonaparte Group (Formation in Warris, 1993) offshore. Ningbing reefs are located on high-standing fault blocks on the western side of the Paleozoic basin (Warris, 1993; Gunn, 1988b). Gas discoveries at Garamala-1 are in the carbonate shelf rocks of the Langfield Formation (Group in Warris, 1993). Marine shales of the Bonaparte Group (Formation in Warris, 1993) seal these traps.

Turbidite sandstones of $25 \%$ porosity and 500 millidarcy $(\mathrm{mD})$ permeability within the Milligans Formation are oil and gas reservoirs at Waggon Creek-1 (Fig. 6) (DPIE, 1998; Jefferies, 1988). Shallow marine sandstones at Barnett and Turtle contain both oil and gas shows but may not be good quality reservoirs (DPIE, 1998; Jefferies, 1988). Carbonates of the Tanmurra Formation also contain oil at Turtle.

The Turtle discovery has several other oil reservoir horizons, in addition to the Milligans Formation, including the Carboniferous Kuriyippi Formation of the Kulshill Group, which consists of fluvial and shallow marine sandstones with porosity of $20 \%$ and 
good permeability (DPIE, 1998). The Kuriyippi Formation is present in the Lacrosse terrace and Plover shelf area and is as much as 1,017 m thick in the southern Petrel subbasin. The sandstone, conglomerate and tillite at the top of the formation are interpreted to be of glacial origin (Mory, 1988). The Lower Permian Keyling Formation is also part of the Kulshill Group (Fig. 5), and three oil shows in that unit were reported by Jefferies (1988). The Keyling Formation is described as dominantly clastic with minor limestones and coals and is distributed across the Lacrosse terrace and Plover shelf. In the southern Petrel sub-basin, the Keyling Formation is as much as $973 \mathrm{~m}$ thick (Mory, 1988).

Gas shows were reported in the Lower Permian Fossil Head Formation and the Upper Permian Hyland Bay Formation of the Permian-Triassic Kinmore Group (Jefferies, 1988). The Fossil Head Formation, as much as $650 \mathrm{~m}$ thick in the southern Petrel sub-basin, is described by Mory (1988) as siltstones and sandstones with minor limestones. The Hyland Bay Formation is widely distributed across the Bonaparte basin and consists of as much as $520 \mathrm{~m}$ of carbonates, sandstones, mudstones, and coals that were deposited in shelf and deltaic environments (Mory, 1988; Gunn, 1988b).

\section{Seal Rock}

The Lower Permian Treachery Shale of the Kulshill Group is a regional seal in the onshore and offshore Petrel sub-basin (Figs. 5 and 7) (DPIE, 1998). The Treachery Shale, consisting of carbonaceous shale and tillite, is present across the Petrel sub-basin and on the Plover-Lacrosse terrace, and is as much as $219 \mathrm{~m}$ thick, (McConachie, 1996). Intraformational seals in the Kulshill Group are locally important in the Turtle-Barnett area (McConachie, 1996).

\section{Trap Types}

Anticlines are the most common type of hydrocarbon trap for accumulations of both oil and gas in the two Paleozoic petroleum systems. Draping structures are also important along with fault blocks and reefs. These traps involve Paleozoic sandstone reservoirs and contain approximately $1 \%$ of the reported oil equivalent reserves in the province (Petroconsultants, 1996). Middle Triassic to Early Jurassic regional compression uplifted the flanks of the sub-basin, causing erosion of the margins and forming inversion anticlines associated with fault blocks, large anticlines and monoclines (DPIE, 1998).

\section{KEYLING, HYLAND BAY-PERMIAN 391002 Petroleum Occurrence}

Significant early offshore discoveries include gas at Petrel and Tern in 1969 and 1971 from the Lower Permian Hyland Bay Formation (Fig. 8) (Gunn, 1988b; Mory, 1988) and oil in 1972 from Puffin-1 in the Vulcan graben sub-basin, Territory of Ashmore and Cartier Islands.

Gas discoveries dominate in the central portions of the Petrel sub-basin. Oil gravity ranges from $30^{\circ}-36^{\circ} \mathrm{API}$ and $50^{\circ} \mathrm{API}$ in liquids associated with the Petrel gas discovery. A pipeline is planned for two of these gas discoveries to Darwin (Fig. 2) (DPIE, 1998).

\section{Source Rock}

The Keyling, Hyland Bay-Permian TPS 391002, contains one source-rock complex and two assessment units, the Petrel assessment unit 39100201 and the Vulcan assessment unit 39100202 (Fig. 8). This petroleum system includes the commercial gas 
and condensate discoveries at Petrel and Tern (Fig. 8) sourced by the Lower Permian Keyling Formation and the Upper Permian Hyland Bay Formation (Figs. 5 and 9). The Keyling Formation consists of delta-plain coals and marginal marine shales deposited in the Petrel sub-basin north of the Carboniferous depocenter (Gunn, 1988b). The Keyling source rock is characterized by high organic carbon and fair source quality, TOC $35 \mathrm{wt} \%$ and HI $230 \mathrm{mgHC} / \mathrm{gTOC}$ for the coals and TOC $2.8 \mathrm{wt} \%$ and HI $95 \mathrm{mgHC} / \mathrm{gTOC}$ for the shales (Edwards and others 1997). Mory (1988) defines the formation as the third unit of the Kulshill Group that thickens toward the Malita sub-basin (Fig. 4, C-D and E-F) (DPIE, 1998). It conformably overlies the Treachery Shale and is in diachronous contact with the overlying Fossil Head Formation. The Keyling Formation is as much as $973 \mathrm{~m}$ thick in Tern-1 and is present on the Lacrosse terrace and Plover shelf (Fig. 4, E-F) (Mory, 1988).

The Upper Permian Hyland Bay Formation is as much as 520 m thick (Mory, 1988) and contains prodelta shales high in gas-prone organic carbon. These shales contain TOC of $2 \mathrm{wt} \%$ and HI of $55 \mathrm{mgHC} / \mathrm{gTOC}$ (DPIE, 1998). Other reported values are TOC $1.6 \mathrm{wt} \%$, HI $125 \mathrm{mgHC} / \mathrm{gTOC}, \mathrm{R}_{\mathrm{o}} 0.9 \%$ at Petrel-2 and TOC $10 \mathrm{wt} \%$, HI 240 $\mathrm{mgHC} / \mathrm{gTOC}, \mathrm{R}_{\mathrm{o}} 0.7 \%$ at Bougainville-1 (McConachie and others, 1996). Possible oilprone source rocks from the Upper Permian section have TOC of 15wt\%, HI of 250-500, and $\mathrm{R}_{\mathrm{o}} 0.6 \%$ at the eastern side of the sub-basin.

Peak generation from Keyling and Hyland Bay source rocks occurred during the Middle Triassic and Late Cretaceous-Tertiary with possible expulsion for the Keyling Formation as early as Late Permian (Fig. 9) (Edwards and others, 1997; DPIE, 1998). Late Permian-Early Triassic maturation and migration of hydrocarbons from the Keyling Formation is expected if high quality coaly shales that are present on the eastern, Moyle platform side of the Petrel sub-basin, extend and thicken into the sub-basin (Edwards and others,1997). Maturation modeling suggests peak generation and migration from the Hyland Bay Formation in Late Cretaceous through Tertiary time and (depending on modeled overburden thickness) Early Triassic or Middle to Late Triassic from the Keyling Formation (DPIE, 1998).

\section{Reservoir Rock}

Gas and condensate discoveries of the Keyling/Hyland Bay-Permian TPS are located in the central portions of the Petrel sub-basin and include Tern and Petrel fields, each estimated to contain recoverable reserves of approximately 600 billion cubic feet of gas (BCFG) (DPIE, 1998). A gas discovery at Fishburn-1 and gas and condensate shows at Penguin-1 are also reported. Most of the discoveries to date are in the Permian Hyland Bay Formation of the Kinmore Group (Fig. 5) (DPIE, 1998). Paleogeographic maps show that a large lower delta plain, prograding northwestward, occupied the Petrel subbasin from Latest Carboniferous to Late Permian time (Mory, 1988; McConachie and others, 1996). At Petrel and Tern fields, the Hyland Bay Formation is 400-500 m thick and is characterized by sandstones and mudstones with minor coals and limestones. The main gas reservoirs of Petrel field are three, 5 m-thick, stacked, fluvial-marine deltaic sandstones, with 23\% porosity, in the Cape Hay Member of the Hyland Bay Formation (Gunn, 1988b; DPIE, 1998). Good permeability is indicated by high flow rates. Reservoir quality is facies dependent and relies on clay coatings on sand grains to inhibit quartz overgrowth and preserve primary porosity (Bhatia and others, 1984; Gunn, 1988b). The reservoir at Tern field is the sandstone unit of the Tern Member of the 
Hyland Bay Formation with an average porosity of $20 \%$, where quartz overgrowth has been inhibited by clay coatings, and good flow rates were reported indicating good permeability (DPIE, 1998; Gunn, 1988b; Gunn and Ly, 1989). The Tern Member is interpreted as originating in a barrier bar environment (Bhatia and others, 1984). The reservoir at the Fishburn-1 gas discovery and oil and gas shows at Torrens- 1 are also considered to be in the Upper Permian Hyland Bay Formation (Fig. 8) (DPIE, 1998).

\section{Seal Rock}

Gas reservoirs in the Petrel field are sealed by intraformational shales in the Kinmore Group (Gunn, 1988b). The seal at the Tern field consists of the overlying shallow marine Mount Goodwin Formation of the Kinmore Group (Figs. 5 and 9) (Gunn, 1988b; DPIE, 1998). The Mount Goodwin Formation is present across the Londonderry high and the Petrel sub-basin and varies from 150-670 $\mathrm{m}$ in thickness (Mory, 1988).

Paleozoic claystone seals are proven in the eastern arm of the province and the Paleozoic unconformity in this region may act as a seal where it is coupled with overlying marine shales rather than sandstones (McLennon and others, 1990).

\section{Trap Types}

Anticlines are the most common type of trap for accumulations of both oil and gas in the petroleum system. Draping structures are also important. These traps contain approximately $30 \%$ of the reported oil equivalent reserves in the province (Petroconsultants, 1996). The Middle Triassic to Early Jurassic regional compression also affected this area, resulting in uplift and the formation of inversion anticlines, large anticlines, and monoclines (DPIE, 1998).

\section{MESOZOIC PETROLEUM SYSTEM JURASSIC, EARLY CRETACEOUS-MESOZOIC 391003 \\ Petroleum Occurrence}

Since 1986, drilling in the Vulcan graben sub-basin and its adjacent margins, the Ashmore block and Londonderry high, has led to several oil and gas discoveries with oil production from three fields: Cassini, Challis, and Jabiru, (Fig. 10). These fields are located in structurally high fault blocks, horsts, or inverted grabens (Nelson, 1989), parallel to and within the Vulcan graben sub-basin and adjacent to deep troughs. Oil and gas occurs in Jurassic and Triassic reservoirs that are unconformably overlain by Lower Cretaceous strata (Nelson, 1989; Gorman, 1990). These fields were subsea completed and produced through floating facilities. Total oil production dropped from a high of 24.7 million barrels of oil (MMBO) in 1992 to $9.3 \mathrm{MMBO}$ in 1995 (Australian Institute of Petroleum Ltd., 1996). Reported API gravity for Mesozoic discoveries ranges from $40^{\circ}$ to $60^{\circ}$ with gas to oil ratio (GOR) ranging from 40 to 768 (Gorman, 1990). The oils are described as low in sulfur (0.13\% at Challis) (Wormald, 1988) and metals content (Miyazaki, 1989), paraffinic based (80\% at Challis) (Wormald, 1988), and with low viscosity (Gorman, 1990). A pipeline is proposed from the Bayu/Undan gas discoveries in the ZOC to Darwin (Figs. 2 and 10) (DPIE, 1998). Reserves for the Bayu/Undan field are estimated at 3.4 trillion cubic feet of gas (TCFG) and 404 MMB liquids (World Oil, 1999). This pipeline may facilitate development of other discoveries. Oil has been discovered in Corallina, Laminaria, and Jahal in the northern Sahul syncline of the Timor Sea (Fig. 10). Recent gas discoveries, Sunrise and Troubadour fields, have also been drilled to the east of the ZOC on the Sahul platform (Fig. 10). The Elang-1 discovery 
encountered a $76.5 \mathrm{~m}$ gross column of $56^{\circ}$ API oil in a fault block trap (Young and others, 1995). The oil at Elang-1 is undersaturated with a GOR of 550 (Young and others, 1995). Production from Elang-1, 2 and Kakatua-1 in the ZOC began in July 1998 using a floating production facility (Fig. 10) (World Oil, 1999). Combined reserves at Elang and Kakatua are estimated at more than 29 MMBO (World Oil, 1999).

Oil and gas accumulations in Mesozoic strata are found in (1) trapping structures that overlie subsided areas where source rock was deposited and is mature, and where faults facilitated vertical migration; and (2) in traps directly adjacent to the subsided areas of mature source rocks, where there was vertical migration out of the syncline followed by lateral migration into adjacent reservoir rocks.

\section{Source Rock}

The Jurassic, Early Cretaceous-Mesozoic TPS 391003 contains source rocks of Jurassic and Early Cretaceous age and sandstone reservoirs of various Mesozoic ages that were deposited in a complex of sub-basins formed by Mesozoic faulting and subsidence (Fig. 11). One assessment unit has been assigned to this TPS, Malita 39100301 (Fig. 10). Specific stratigraphic names and ages vary locally among areas. In particular, terminology from exploration leases assigned to different companies in this unit has not been fully correlated in the literature and reflects local differences in deposition and erosion (Fig. 5). The Pliensbachian to Callovian Plover Formation consists of organicrich claystones and coals deposited in fluvial to marginal marine environments (Botten and Wulff, 1990). Residual oils from wells on the Londonderry high have been typed to this claystone in the Sahul syncline (Fig. 4, A-B) (Whibley and Jacobson, 1990). The source potential is fair to good for gas/condensate and some oil; TOC $\Rightarrow 4 \mathrm{wt} \%, \mathrm{~S}_{1}+\mathrm{S}_{2}$ (petroleum potential) approximately $8 \mathrm{mg} / \mathrm{g}$ (Botten and Wulff, 1990). The Oxfordian to Valanginian Flamingo Group (Upper Petrel Formation) has good oil source-rock potential in the Bonaparte Basin; TOC ranges from 1-2.4 wt $\%$ and $\mathrm{S}_{2}$ values range from 2-3.1 mg/g (Botten and Wulff, 1990; McLennan and others, 1990). The Oxfordian to Valanginian interval is also known as part of the Elang Formation (Plover Formation), Frigate Formation (Frigate Shale, Sandpiper sands), Flamingo Formation (Flamingo shale, Darwin Formation), and part of the Echuca Shoals Formation (Darwin Formation) (Brooks and others, 1996). Burial history models for the Flamingo and Sahul synclines indicate initial source-rock maturation at the start of the Paleocene for Upper Flamingo claystones in the Flamingo syncline, and in the Cretaceous for the Sahul syncline (Brooks and others, 1996). Peak oil generation of Upper Flamingo claystones in the Sahul syncline was in Late Cretaceous time, and in the Flamingo syncline in Middle Eocene time (Brooks and others, 1996). Equivalent Mesozoic source rocks in the Malita graben matured and expelled hydrocarbons during latest Cretaceous to Tertiary subsidence (Miyazaki, 1997). At present, Mesozoic source rocks may still be generating gas in the Malita graben (Fig. 4, A-B and C-D) (Miyazaki, 1997).

The Valaginian-Barremian Darwin Formation (Echuca Shoals Formation) and the Turonian-Maastrichtian Bathurst Island Group (Fig. 5) also have good source-rock properties but are immature or marginally mature for oil over most of the area (Fig. 4, AB and C-D) (Robinson and others, 1994). The restricted marine shale of the Darwin Formation is interpreted to be an excellent source rock and to be mature in the Sahul and Flamingo synclines (Brooks and others, 1996). These strata overlie most of the good reservoir rocks in the area so migration would require faulting to position older reservoir 
rocks updip from local, low lying mature areas (Fig. 4, A-B and C-D) (Robinson and others, 1994). Oil at Elang-1 is geochemically mature, vitrinite reflectance $=0.9-1.1$, and is derived from a source rock of algal/marine organic matter with a terrestrial component (Young and others 1995). The Darwin Formation in the Sahul syncline and Malita graben is suggested as the source rock for this oil (Young and others, 1995). Condensate from the Bayu/Undan area has been closely correlated to claystones of the Echuca Shoals Formation (Fig. 5) (Brooks and others, 1996). Migration is considered to be out of the Malita graben, where the Echuca Shoals Formation is thought to be thicker and more deeply buried, or possibly from the Flamingo syncline (Brooks and others, 1996).

The Jurassic-Cretaceous Lower and Upper Vulcan Formations (Frigate and Flamingo equivalents) of the Swan Group, with possible contributions from the Lower Cretaceous Echuca Shoals Formation of the Bathurst Island Group, provide source rocks for gas, oil, and condensate accumulations within the Vulcan graben sub-basin (Fig. 5) (Bourne and Faehrmann, 1991; Smith and Sutherland, 1991). Late Jurassic and Early Cretaceous source rocks are juxtaposed by normal faulting against Triassic and Early Jurassic reservoir rocks (Bourne and Faehrmann, 1991; Pattillo and Nicholls, 1990). Hydrocarbons migrate along sandstone units and across faults to source reservoirs in high-standing and basin-margin fault blocks (Bourne and Faehrmann, 1991).

Drilling of Paqualin-1, to test a salt structure, encountered more than 1,640 m of Upper and Lower Vulcan Formation claystones of restricted marine origin (Smith and Sutherland, 1991). Geochemical analysis indicates excellent oil and gas source-rock quality; type II/III kerogen, TOC averaging $2 \mathrm{wt} \%$, HI as much as $300 \mathrm{mgHC} / \mathrm{gTOC}$, and $\mathrm{S}_{1}+\mathrm{S}_{2}$ (petroleum potential) $\approx 6.0 \mathrm{mg} / \mathrm{g}$ (Smith and Sutherland, 1991).

The Lower to Middle Jurassic Plover Formation is present only within the Vulcan graben sub-basin; the formation was eroded or was not deposited across the Ashmore platform and is only partially preserved on the Londonderry high. The Plover Formation is a possible gas-prone source rock of fluvial deltaic sandstones and carbonaceous deltaic mudstones. The possible source of hydrocarbons on the Ashmore platform would be thick, shallow, and marginal marine facies of the Triassic Sahul Group (DPIE, 1998). Hydrocarbons in fields on the structural terraces surrounding the Londonderry high (Challis field) and Ashmore platform (Puffin and Skua fields) probably migrated from the local troughs within the Vulcan graben sub-basin where Upper Jurassic source rock is present and buried to depths of 4,000 m (Wormald, 1988; Ormerod and others, 1995).

\section{Reservoir Rock}

The Lower Jurassic (Rhaetian-Pleisbachian) Malita Formation consists of sandstones and shales of continental redbed and shallow marine to fluvial-deltaic origin (Killick and Robinson, 1994). These rocks reach thicknesses of more than $500 \mathrm{~m}$ in the Sahul syncline but are present on the Sahul platform in thicknesses less than $25 \mathrm{~m}$. Fluvial influence is greater in the lower Malita and increases to the south whereas marine influence is greater in the upper Malita and increases to the north (Killick and Robinson, 1994).

The lower Plover Formation is characterized by strata deposited in a regressive fluvial-deltaic depositional environment (Killick and Robinson, 1994). The upper Plover was deposited in a transgressive nearshore marine setting. On the margins of the Petrel sub-basin the Plover Formation reaches a thickness of $200 \mathrm{~m}$ and in the Sahul syncline a thickness of 1,200 m (Killick and Robinson, 1994). Sedimentation of the Plover 
Formation was controlled by continued subsidence of the Flamingo trough and the Sahul syncline. Significant erosion (possibly $400 \mathrm{~m}$ ) occurred on the Sahul platform during Late Callovian to Early Oxfordian time (Killick and Robinson, 1994). The Callovian to Oxfordian Montara beds at the top of the Jurassic Plover Formation are of fluvio-deltaic to marginal marine origin and have excellent reservoir qualities in the Elang-1 discovery, including porosities of 20-25\% and permeabilities of 880 to $2000 \mathrm{mD}$ (Young and others, 1995; Petroconsultants, 1996).

The Upper Jurassic to Lower Cretaceous Flamingo Group is thin or absent over the Londonderry high and Sahul platform due to nondeposition, low sedimentation rates and erosion (Killick and Robinson, 1994). Several lowstand events during deposition of the Flamingo Group could produce erosion, valley-fill type prospects, and basin-floor fans. The Flamingo Group is more than 1,000 m thick in the Sahul syncline, Flamingo trough and the Malita graben. Subsidence of the Sahul syncline and the Flamingo trough was greatest in Late Jurassic whereas subsidence in the Malita graben was greatest in the Early Cretaceous (Killick and others, 1994). The "sandpiper sands" of Oxfordian to Valanginian age are described as shoreface to marine fan sands, the fans having been deposited by mass flow and rapid traction events.

Oil reserves at Challis and Cassini fields in the Vulcan graben sub-basin are in stacked sandstone reservoirs of the Middle to Upper Triassic Challis and Pollard Formations of the Sahul Group (Gorman, 1990). The reservoir rocks originated in upper deltaic, barrier, and shoreline settings. Sandstones are 100-200 m thick in the deltaic setting and 10-20 m thick in the barrier/shoreline setting. Porosity ranges from $25-30 \%$ and permeability is as much as 10 darcies. Cementation by carbonates and clays and creation of secondary porosity by dissolution of grains and cements has occurred (Gorman, 1990).

Also in the Vulcan graben sub-basin, oil in the Jabiru field is found in Early and Late Jurassic age sandstones, lower Vulcan and Plover Formations of the Swan and Troughton Groups, and beneath the same Early Cretaceous unconformity that traps oil at Challis and Cassini fields. These Jurassic sandstones have porosity of 18-26\% and permeability of 1.6 darcies (Nelson, 1989). Depositional environments are described as coastal and barrier island for the 100-200 m thick Lower Jurassic sandstone reservoirs and nearshore marine for the 10-100 m thick Upper Jurassic reservoirs (Nelson, 1989).

\section{Seal Rock}

Top and lateral seals for the Laminaria field are formed by $300 \mathrm{~m}$ of Lower Cretaceous (Neocomian) claystone of the Upper Flamingo Group and Darwin Formation (Fig. 11). The Frigate Shale provides a seal to the Plover and Malita Formations and the Cape Londonderry Formation where it is present. The Flamingo Shale is both a seal and a source rock in the Mesozoic basins (Figs. 3, 4 and 5). It was deposited when the Malita graben was subsiding and capturing sediments from the south while the north was more distal and starved of sediment (Fig. 5) (Killick and others, 1994). The thick Cretaceous Bathurst Island Group shale is the regional seal for the Mesozoic basins.

\section{Trap Types}

Most of the reserves reported (Petroconsultants, 1996) in the Mesozoic petroleum system occur in fault-block traps. This petroleum system accounts for $67 \%$ of the oil equivalent reserves in the Bonaparte Gulf Basin Province (Petroconsultants, 1996). The Vulcan graben is dominated by horst-blocks traps. Kimmeridgian faulting further 
subdivided Callovian fault blocks into narrower grabens and fault block trends (Pattillo and Nicholls, 1990) and changed the earlier structural grain from NE-SW to ENE.

Late Miocene to Pliocene collision tectonics reactivated many Late Jurassic normal faults, mobilized Paleozoic salt in the Vulcan graben, formed possible inverted structures, and increased the risk of releasing trapped hydrocarbons (DPIE, 1998; Pattillo and Nicholls, 1990; Bourne and Faehrmann, 1991; Smith and Sutherland, 1991).

\section{OVERBURDEN ROCK}

The Tertiary of the Bonaparte Gulf Basin Province is characterized by formation of a mature passive margin of carbonate deposition (Fig. 5) (Pattillo and Nichols, 1990). Lowstand sands were deposited during the Eocene and Miocene on this carbonate shelf (Pattillo and Nichols, 1990).

Overburden is thin in the Petrel sub-basin, and consists of shallow shelf and continental clastic deposition changing to clastic and carbonate deposition as subsidence shifted to the northern portions of the province during Mesozoic time. Some of the offshore areas, as well as all of the onshore Petrel sub-basin, were characterized by nondeposition or erosion during the Cenozoic (Mory, 1988; McConachie and others, 1996). The post-Paleozoic section thickens in a wedge shape from the head of Joseph Bonaparte Gulf northward to where it is overprinted by the opposing Mesozoic MalitaVulcan structural trend. Thickness of this wedge ranges from less that 2,000 $\mathrm{m}$ to more than $8,000 \mathrm{~m}$ resulting in maturation of older source rocks progressively toward the south.

The Malita graben is overlain by Neocomian to Holocene sediments. The Goulburn graben in the easternmost portion of province 3910 consists of pre-Cambrian basement, folded and faulted Paleozoic rocks, and undeformed middle Jurassic to Holocene rocks. Seismic data in the Goulburn graben indicates progradation from the south and southeast (McLennan and others, 1990).

The Cretaceous Bathurst Island Group is both seal and overburden in the Vulcan graben area (Pattillo and Nicholls, 1990). Some good reservoir-quality sandstones occur in this group. These sediments were deposited in a late Campanian lowstand submarine fan complex, sourced from the southeast, that prograded across the Vulcan graben to the Ashmore platform following an Albian to Campanian highstand (Pattillo and Nicholls, 1990).

\section{UNDISCOVERED PETROLEUM}

The Bonaparte Gulf Basin Province (3910) contains three proven petroleum systems with numerous styles and ages of exploration targets and considerable underexplored potential. The eastern arm of the Mesozoic petroleum system (Malita assessment unit, 39100301) contains one gas discovery, Evans Shoal-1 (Fig. 10), and several shows thought to be sourced from this portion of the Malita graben indicating the presence of mature source rocks in the eastern area of the province (DPIE, 1998).

Numerous exploration targets may be present within the Malita graben and on the faulted edges north and south (Figs. 3 and 4 A-B). This eastern area also contains potential exploration targets involving Jurassic and Cretaceous sandstones onlapping basement rock along the northern edge of the Darwin shelf (DPIE, 1998). These onlapping stratigraphic and drape anticline type of prospects should be targets around the entire 
edge of the Darwin shelf. Some of these types of plays have been drilled on the western side of the Bonaparte Gulf, but most of the area of the Darwin shelf and the Moyle platform on the eastern side of the gulf adjacent to the mature Mesozoic system and the mature Paleozoic system remains unexplored (Miyazaki, 1997). On the west side of the Joseph Bonaparte Gulf along the Berkeley platform and the Londonderry high, where drilling has also been sparse, similar onlapping stratigraphic and paleotopographic drape style traps may occur. This play has been successful in the Browse Basin Province (3913) on the western edge of the Londonderry high with discoveries at Gwydion and Cornea (Bishop, 1999).

Fault traps on the margins of the Londonderry high, Laminaria high, Flamingo high, Sahul platform and Troubadour high, adjacent to mature source rocks in the synclines, have been successful exploration targets and could be the sites for additional discoveries (Fig. 3). Lowstand, shallow-water and highstand, deep-water sandstones in the synclines offer numerous under-explored drilling targets. In the Vulcan graben, possible inversion structures similar to Jabiru, along with lowstand valley-fill clastics are potential targets.

Similar lowstand stratigraphic and paleotopographic traps might be encountered in the Paleozoic systems (391001 and 391002) along both the east and west sides of the gulf. High-quality, mature source rocks are predicted adjacent to the Moyle platform on the east side of the Petrel assessment unit (39100201) (Fig. 8) and shows occur to the west on the Plover-Lacrosse terrace and Londonderry high (Edwards and others, 1997).

\section{REFERENCES}

Australian Geological Survey Organisation, 1998, Oil and Gas Resources of Australia: Department of Industry, Science and Resources, Canberra City, Australia, p.168, 1 map.

Australian Institute of Petroleum Ltd., 1996, Oil and Australia, statistical review 1996: Australian Institute of Petroleum Ltd., Supplement to Petroleum Gazette 1996/3, $24 \mathrm{pp}$.

Baxter, K., Cooper, G. T., Hill, K. C., and O’Brien, G. W., 1999, Late Jurassic subsidence and passive margin evolution in the Vulcan Sub-basin, north-west Australia: constraints from basin modelling: Basin Research, v. 11, no. 2, p. 97111.

Bhatia, M. R., Thomas, M., and Boirie, J. M., 1984, Depositional framework and diagenesis of the Late Permian gas reservoirs of the Bonaparte Basin: APEA Journal, v. 24, part 1, p. 299-313.

Bishop, Michele G., 1999, A total petroleum system of the Browse Basin, Australia: Late Jurassic, Early Cretaceous-Mesozoic: US Geological Survey Open File Report 99-50I. http://energy.cr.usgs.gov/energy/WorldEnergy/OF99-50I or http://energy.cr.usgs.gov/energy/WorldEnergy/WEpubs.html.

Bosworth, William, 1985, Geometry of propagating continental rifts: Nature, v. 316, p. 625-627.

Botten, P., and Wulff, K., 1990, Exploration potential of the Timor Gap Zone of Cooperation: APEA Journal, v. 30, part 1, p. 68-90.

Bourne, J. D., and Faehrmann, P. A., 1991, The Talbot oilfield, Vulcan sub-basin, Timor Sea: a Triassic oil discovery: APEA Journal, v. 31, part 1, p. 42-55. 
Brooks, D. M., Goody, A. K., O’Reilly, J. B., and McCarty, K. L., 1996, Bayu/Undan gas-condensate discovery: Western Timor Gap Zone of Cooperation, Area A: APPEA Journal, no. 36, p. 142-160.

DPIE, 1998, Release of Offshore Petroleum Areas Australia 1998; Geology and Data Availability: Canberra, Australia, Department of Primary Industries and Energy, 194 p. and CD-ROM.

Durrant, J. M., France, R. E., Dauzacker, M. V., and Nilsen, T., 1990, The southern Bonaparte Gulf basin—new plays: APEA Journal, v. 30, part 1, p. 52-67.

Edwards, D. S., Summons, R. E., Kennard, J. M., Nicoll. R. S., Bradshaw, J., Bradshaw, M., Foster, C. B., O’Brien, G. W., and Zumberge, J. E., 1997, Geochemical characteristics of Palaeozoic petroleum systems in Northwestern Australia: APPEA Journal, v. 37, part 1, p. 351-379.

Gorman, I. G. D., 1990, The role of reservoir simulation in the development of the Challis and Casini fields: APEA Journal, v. 30, part 1, p. 212-221.

Gunn, P. J., 1988a, Bonaparte Basin: evolution and structural framework, in Purcell, P. G., and Purcell, R. R., eds., The North West Shelf Australia: Proceedings of Petroleum Exploration Society Australia Symposium, Perth, 1988, W. A. PESA, p. 276-285.

Gunn, P. J., 1988b, Hydrocarbon discoveries in the Bonaparte Basin, in Purcell, P. G., and Purcell, R. R., eds., The North West Shelf Australia: Proceedings of Petroleum Exploration Society Australia Symposium, Perth, 1988, W. A. PESA, p. 419-424.

Gunn, P. J., and Ly, K. C., 1989, The petroleum prospectivity of the Joseph Bonaparte Gulf area, Northwestern Australia: APEA Journal, v. 29, part 1, p. 509-526.

Hamilton, Warren, 1974, Map of Sedimentary Basins of the Indonesian Region: USGS Miscellaneous Investigations Series, Map I-875-B, 1:5,000,000.

Hocking, R., Mory, A. J., and Williams, I. R., 1994, An atlas of neoproterozoic and Phanerozoic basins of Western Australia, in Purcell, P. G. and Purcell, R. R., eds., The Sedimentary Basins of Western Australia: Proceedings West Australian Basins Symposium, Perth, W. A., PESA, p. 21-44.

Jefferies, P. J., 1988, Geochemistry of the Turtle oil accumulation, offshore Southern Bonaparte Basin, in Purcell, P. G., and Purcell, R. R., eds., The North West Shelf Australia: Proceedings North West Shelf Symposium 1988, Perth, W. A., PESA, p. 563-569.

Killick, M. F., and Robinson, P. H., 1994, The good and bad of diagenesis-a review of sandstone reservoirs in the North Bonaparte Basin, in Purcell, P. G. and Purcell, R. R., eds., The Sedimentary Basins of Western Australia: Proceedings West Australian Basins Symposium, Perth, W. A., PESA, p. 275-289.

Klett, T.R., Ahlbrandt, T. A., Schmoker, J.W., and Dolton, G. L., 1997, Ranking of the world's oil and gas provinces by known petroleum volumes: U.S. Geological Survey Open-File Report 97-463, one CD-ROM.

Lavering, I. H., and Ozimic, S., 1988, Bonaparte Basin petroleum accumulations, in Purcell, P. G., and Purcell, R. R., eds., The North West Shelf Australia: Proceedings of Petroleum Exploration Society Australia Symposium, Perth, 1988, W. A. PESA, p. 331-337. 
Martin, B. A., and Cawley, S. J., 1991, Onshore and offshore petroleum seepage: contrasting a conventional study in Papua New Guinea and airborne laser fluorosensing over the Arafura Sea: The APEA Journal, v. 31, part 1, p. 333-353.

McConachie, B. A., Bradshaw, M. T., and Bradshaw, J., 1996, Petroleum systems of the Petrel sub-basin-an integrated approach to basin analysis and identification of hydrocarbon exploration opportunities: APPEA Journal, v. 36, part 1, p. 248-268.

McLennan, J. M., Rasidi, J. S., Holmes, R. L., and Smith, G. C., 1990, The geology and petroleum potential of the western Arafura Sea: APEA Journal, v. 30, part 1, p. 91-106.

Mildren, S. D., Hillis, R. R., Fett, T., and Robinson, P. H., 1994, Contemporary stresses in the Timor Sea: implications for fault-trap integrity, in Purcell, P. G. and Purcell, R. R., eds., The Sedimentary Basins of Western Australia: Proceedings West Australian Basins Symposium, Perth, W. A., PESA, p. 291-300.

Miyazaki, S., 1997, Australia's southeastern Bonaparte basin has plenty of potential: Oil and Gas Journal, April 2, 1997, p. 78-81.

Mory, A. J., 1988, Regional geology of the offshore Bonaparte Basin, in Purcell, P. G., and Purcell, R. R., eds., The North West Shelf Australia: Proceedings of Petroleum Exploration Society Australia Symposium, Perth, 1988, W. A. PESA, p. 287-309.

Nelson, Andrew, 1993, Wrench and inversion structures in the Timor Sea region: PESA Journal, no. 21, p. 3-30.

Nelson, A. W., 1989, Jabiru field-horst, sub-horst or inverted graben?: APEA Journal, v. 29, part 1, p. 176-194.

O'Brien, Geoffrey W., 1993, Some ideas on the rifting history of the Timor Sea from the integration of deep crustal seismic and other data: PESA Journal, no. 21, p. 95113.

Oil and Gas Journal, 2000, OGJ Newsletter, February 28, 2000, p. 3.

Ormerod, D., Whittam, D., and Fittall, M., 1995, Puffin Formation sequence stratigraphy in the southern Timor Sea, in Caughey, Charles A., Carter, David C., Clure, John, Gresko, Mark J., Lowery, Philip, Park, Robert K., and Wonders, Antoine, eds., Symposium on Sequence Stratigraphy in SE Asia: Proceedings of the International Indonesian Petroleum Association, May 1995, p. 485.

Pattillo, J. and Nicholls, P. J., 1990, Tectonostratigraphic framework for the Vulcan Graben, Timor Sea region: APEA Journal, v. 30, part 1, p. 27-51.

Petroconsultants, 1996, Petroleum Exploration and Production Database: Petroconsultants, Inc., P.O. Box 740619, 6600 Sands Point Drive, Houston TX 77274-0619, USA or Petroconsultants, Inc., P.O. Box 152, 24 Chemin de la Mairie, 1258 Perly, Geneva, Switzerland.

Robinson, P. H., Stead, H. S., O’Reilly, J. B., and Guppy, N. K., 1994, Meanders to fans: a sequence stratigraphic approach to upper Jurassic - lower Cretaceous sedimentation in the Sahul syncline, north Bonaparte Basin, in Purcell, P. G. and Purcell, R. R., eds., The Sedimentary Basins of Western Australia: Proceedings West Australian Basins Symposium, Perth, W. A., PESA, p. 223-242.

Smith, P. M., and Sutherland, N. D., 1991, Discovery of salt in the Vulcan Graben: a geophysical and geological evaluation: APEA Journal, v. 31, part 1, p. 229-243. 
Summons, Roger E., Bradshaw, John, Brooks, Deirdre M., Goody, Angus K., Murray, Andrew P., and Foster, Clinton B., 1993, Hydrocarbon composition and origins of coastal bitumens from the Northern Territory, Australia: PESA Journal, no. 21, p 31-42.

Warris, B. J., 1993, The hydrocarbon potential of the Palaeozoic basin of Western Australia: APEA Journal, v. 33, part 1, p. 123-137.

Whibley, M., and Jacobson, T., 1990, Exploration in the Northern Bonaparte Basin, Timor Sea - WA-199-P: APEA Journal, v. 30, part 1, p 7-25.

Woods, E. P., 1988, Extensional Structures of the Jabiru Terrace, Vulcan Sub-basin, in Purcell, P. G., and Purcell, R. R., eds., The North West Shelf Australia: Proceedings North West Shelf Symposium 1988, Perth, W. A., PESA, p. 311-330.

Woods, E. P., 1994, A salt-related detachment model for the development of the Vulcan sub-basin, in Purcell, P. G. and Purcell, R. R., eds., The Sedimentary Basins of Western Australia: Proceedings West Australian Basins Symposium, Perth, W. A., PESA, p. 259-274.

World Oil, 1999, Record levels cool down: World Oil, August 1999, p. 115-118.

Wormald, G. B., 1988, The geology of the Challis oilfield - Timor Sea, Australia, in Purcell, P. G., and Purcell, R. R., eds., The North West Shelf Australia: Proceedings North West Shelf Symposium 1988, Perth, W. A., PESA, p. 425-437. Young, I. F., Schmedje, T. M., and Muir, W. F., 1995, The Elang Oil Discovery Bridges the Gap in the Eastern Timor Sea (Timor Gas Zone of Cooperation): Proceedings Indonesian Petroleum Association Twenty Fourth Annual Convention, Volume I, p. 47-69. 


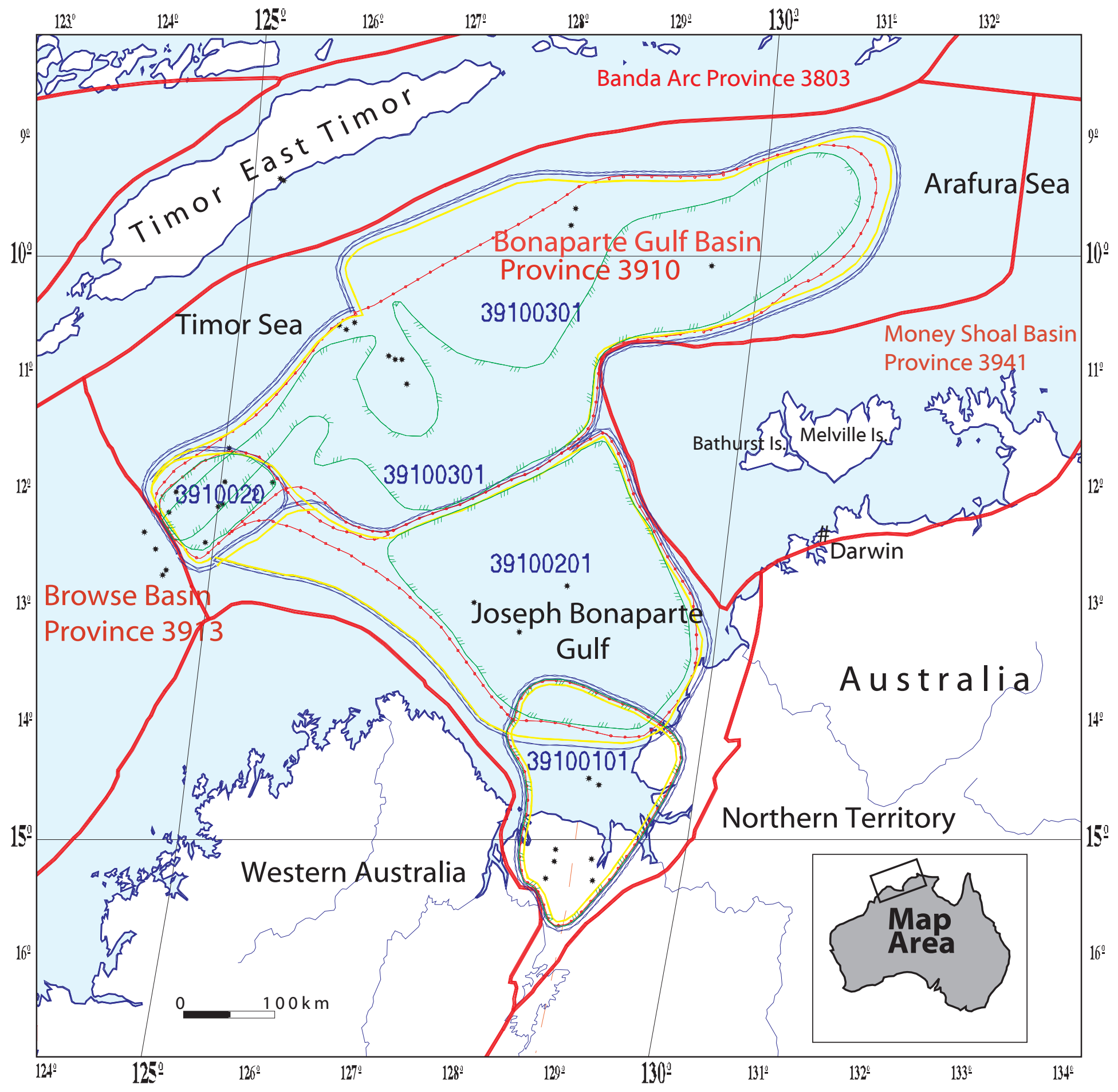

Projection: Robinson. Central meridian: 0 EXPLANATION Assessment unit and code boundary

- Rivers

- Shoreline

Geologic Province boundary

* Field locations, Petroconsultants, 1996

\# Cities
Minimum petroleum system boundary, proven hydrocarbons

Total petroleum system boundary, proven and possible hydrocarbons

Pod of active source rocks boundary

Figure 1. Index map of USGS Province 3910 Bonaparte Gulf Basin, Australia. Three petroleum systems, Milligans-Carboniferous, Permian (391001), Keyling, Hyland Bay-Permian (391002), and Jurassic, Early Cretaceous-Mesozoic (391003) containing four assessment units, Barnett (39100101), Petrel (39100201), Vulcan (39100202), and Malita (39100301) are shown. Basemap provided by Feliks Persits and Doug Steinshouer. 


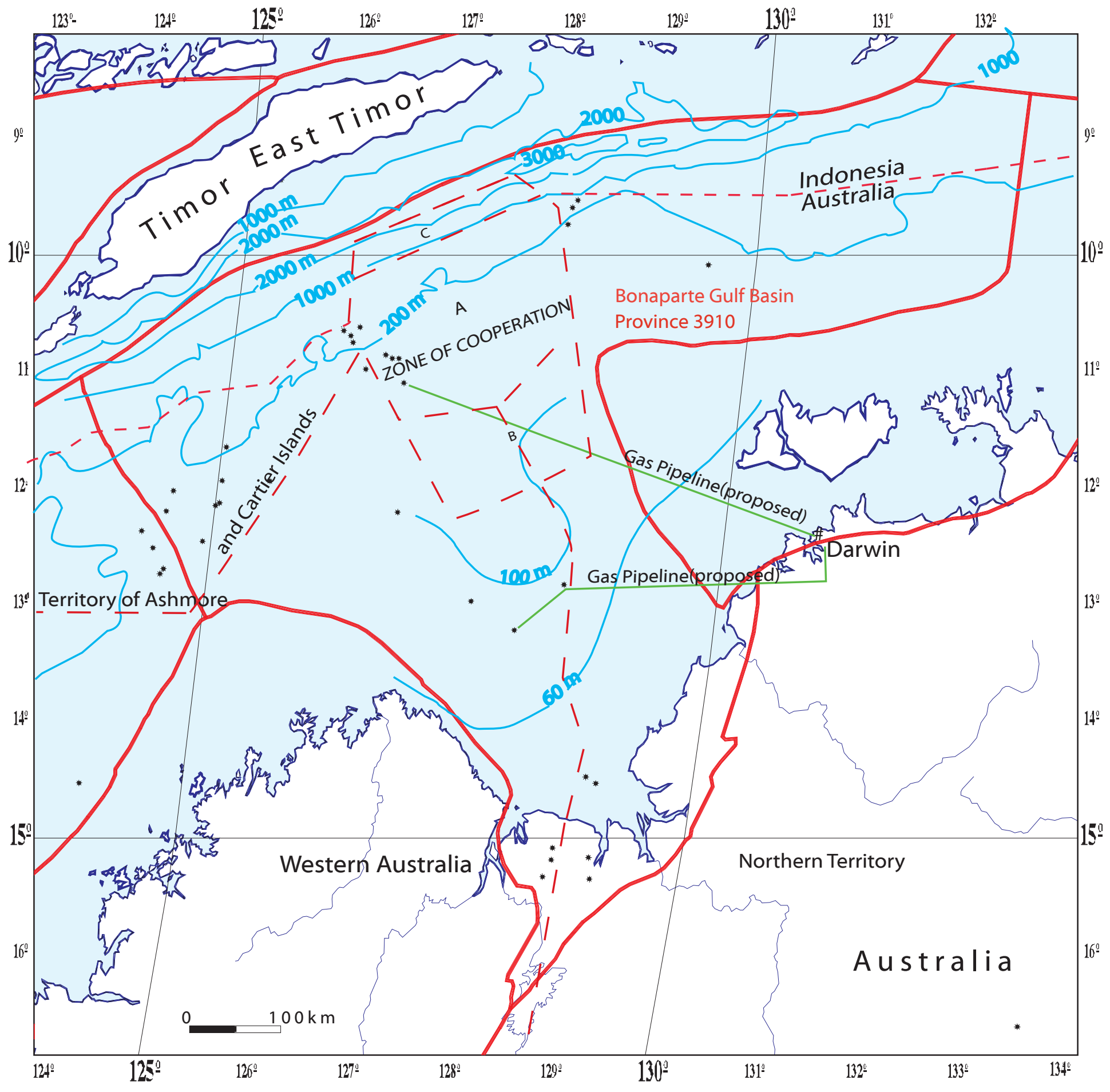

EXPLANATION

— Rivers

* Geologic Province boundary
- Country Boundary

* Field locations, Petroconsultants, 1996

\# Cities

Figure 2. Map of USGS Province 3910 showing bathymetry, Australian state bounderies and international bounderies. The Zone of Cooperation (ZOC) is controled by C, East Timor; A, Australia and East Timor; B, Australia. Information adapted from DPIE, 1998; Hamilton, 1974. 


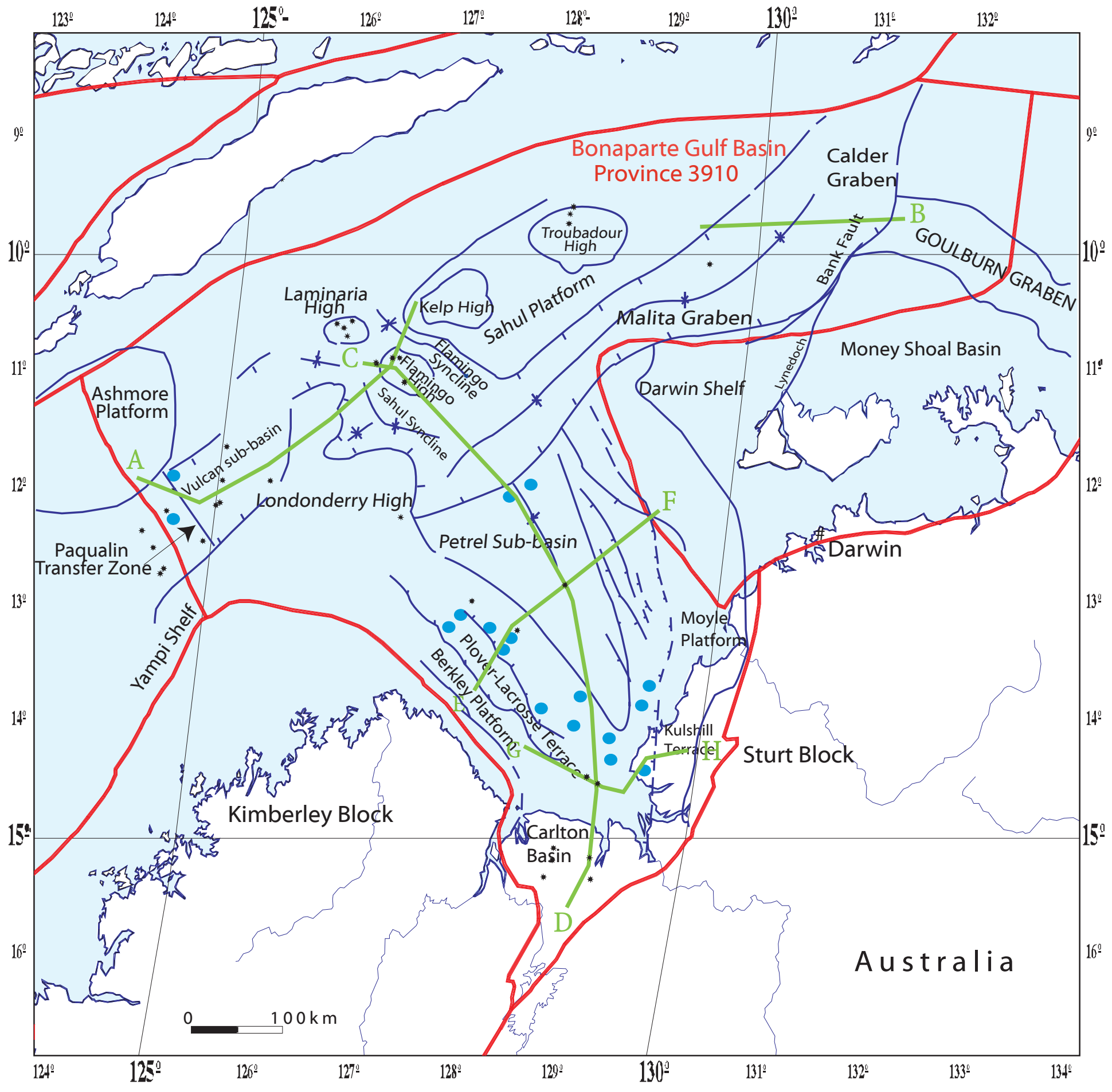

EXPLANATION

— Rivers

- Shoreline

* Field locations, Petroconsultants, 1996

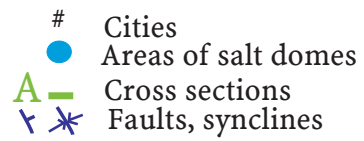

Figure 3. Map of USGS Province 3910 summarizing general structural features, faults, synclines, highs, platforms, and terraces. Cross sections from figure 4 are located. Information compiled from DPIE, 1998; Durrant and others, 1990; Gunn and Ly, 1989; Woods, 1988; Gunn,1988b. 
ASHMORE VULCAN GRABEN PLATFORM SUB-BASIN
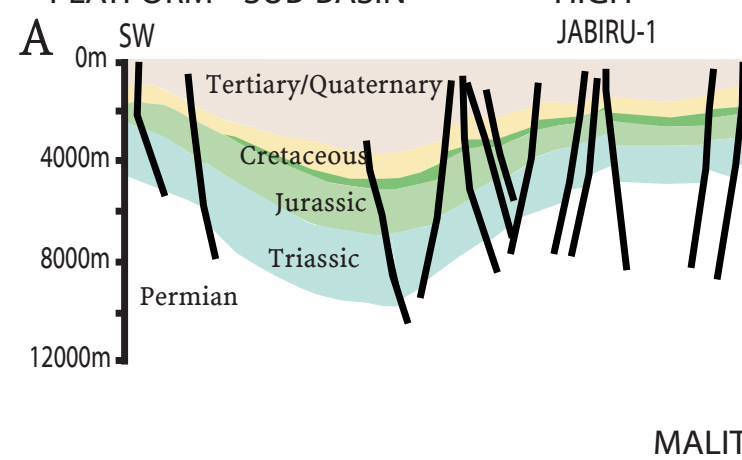

GRABEN
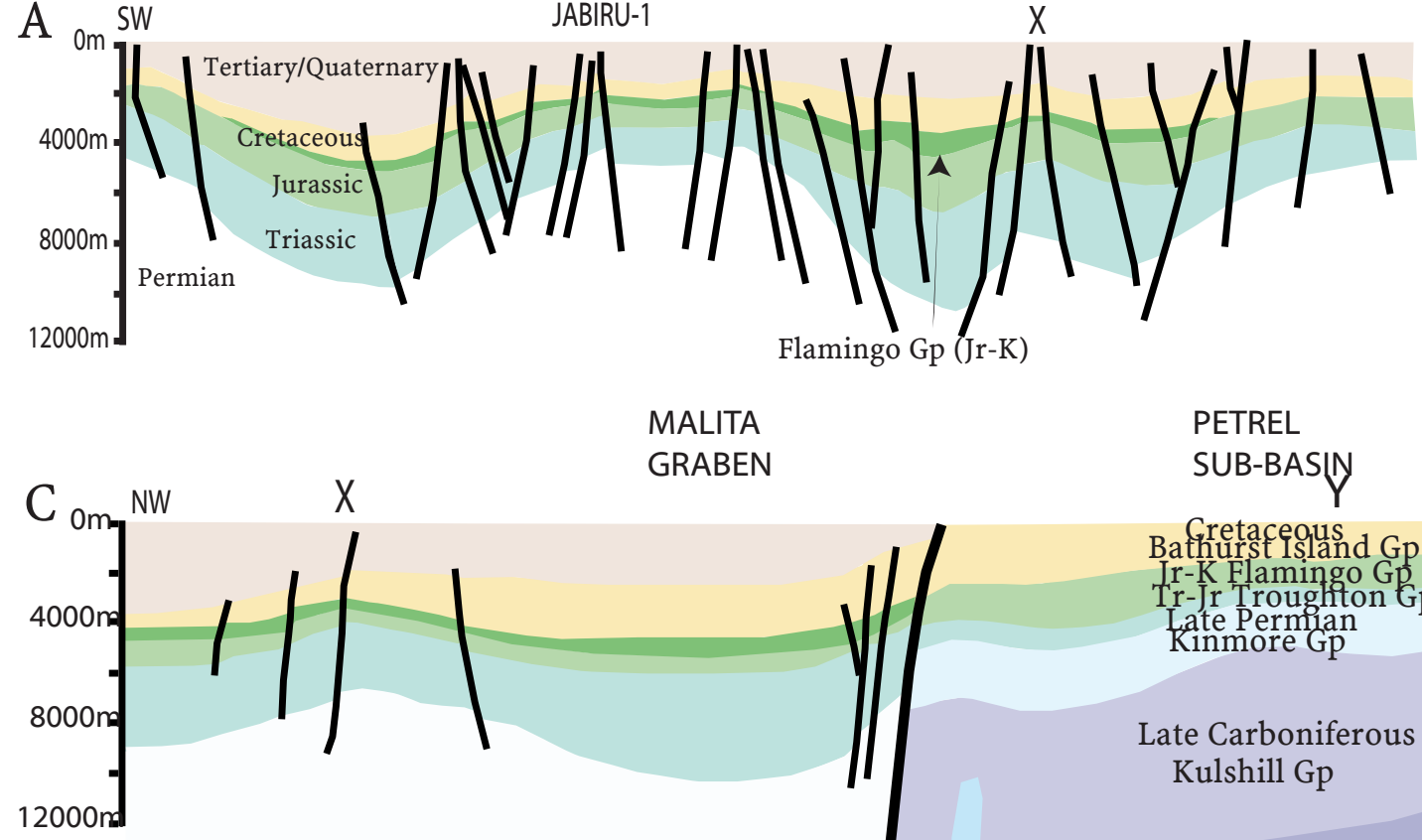

Flamingo Gp (Jr-K)
SAHUL FLAMINGO SAHUL SYNCLINE SYNCLINE PLATFORM
PETREL

SUB-BASIN
MALITA GRABEN
GOULBURN GRABEN

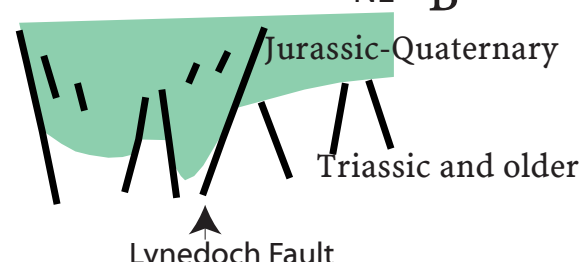

Lynedoch Fault

Barnett

assessment uspi

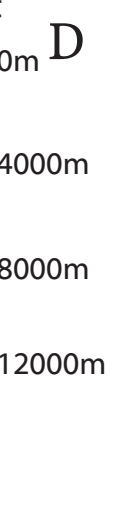

Axial Intrusion

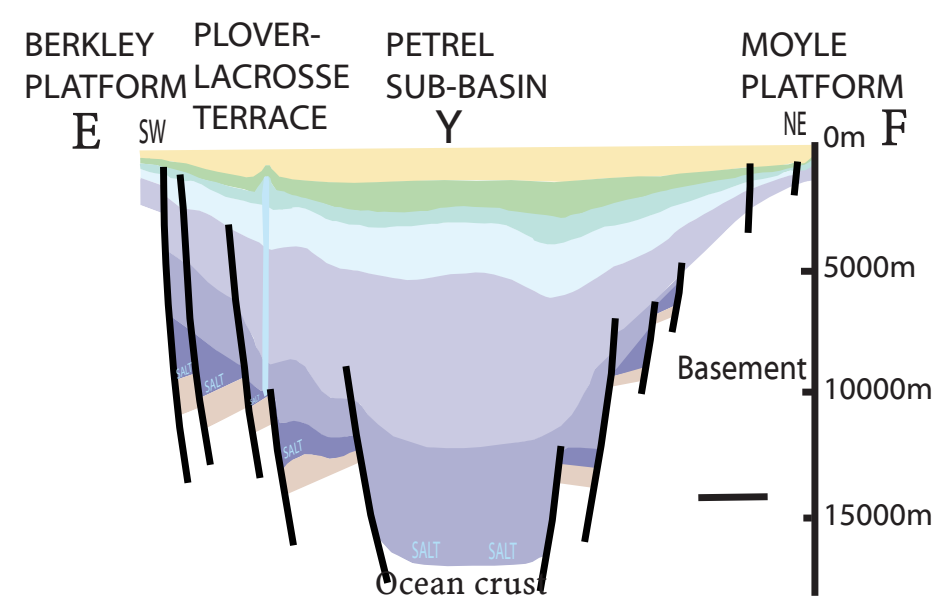

Barnett

PLOVER- a s s s s m e n $\mathrm{t}$ KULSHILL

LACROSSE unit TERRACE

$\mathrm{G}^{\text {TERRACE }} \mathrm{Z}$

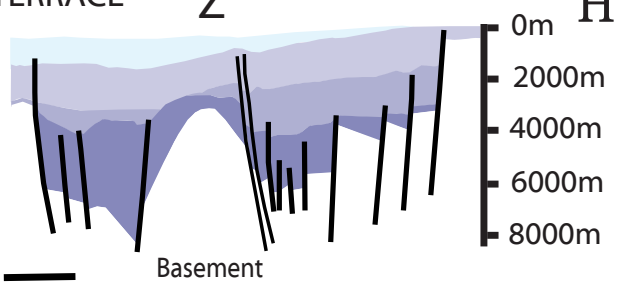

Figure 4. Simplified and combined cross sections of province 3910. Locations found on figure 3. Lines A-B and C-D cross at $\mathrm{X}, \mathrm{C}-\mathrm{D}$ and $\mathrm{E}-\mathrm{F}$ cross at $\mathrm{Y}$, and $\mathrm{C}-\mathrm{D}$ and $\mathrm{G}-\mathrm{H}$ cross at $\mathrm{Z}$. No horizontal scale. Modified and compiled from Botten and Wulff,1990; Gunn and Ly, 1989; DPIE, 1998; and Gunn, 1988. 


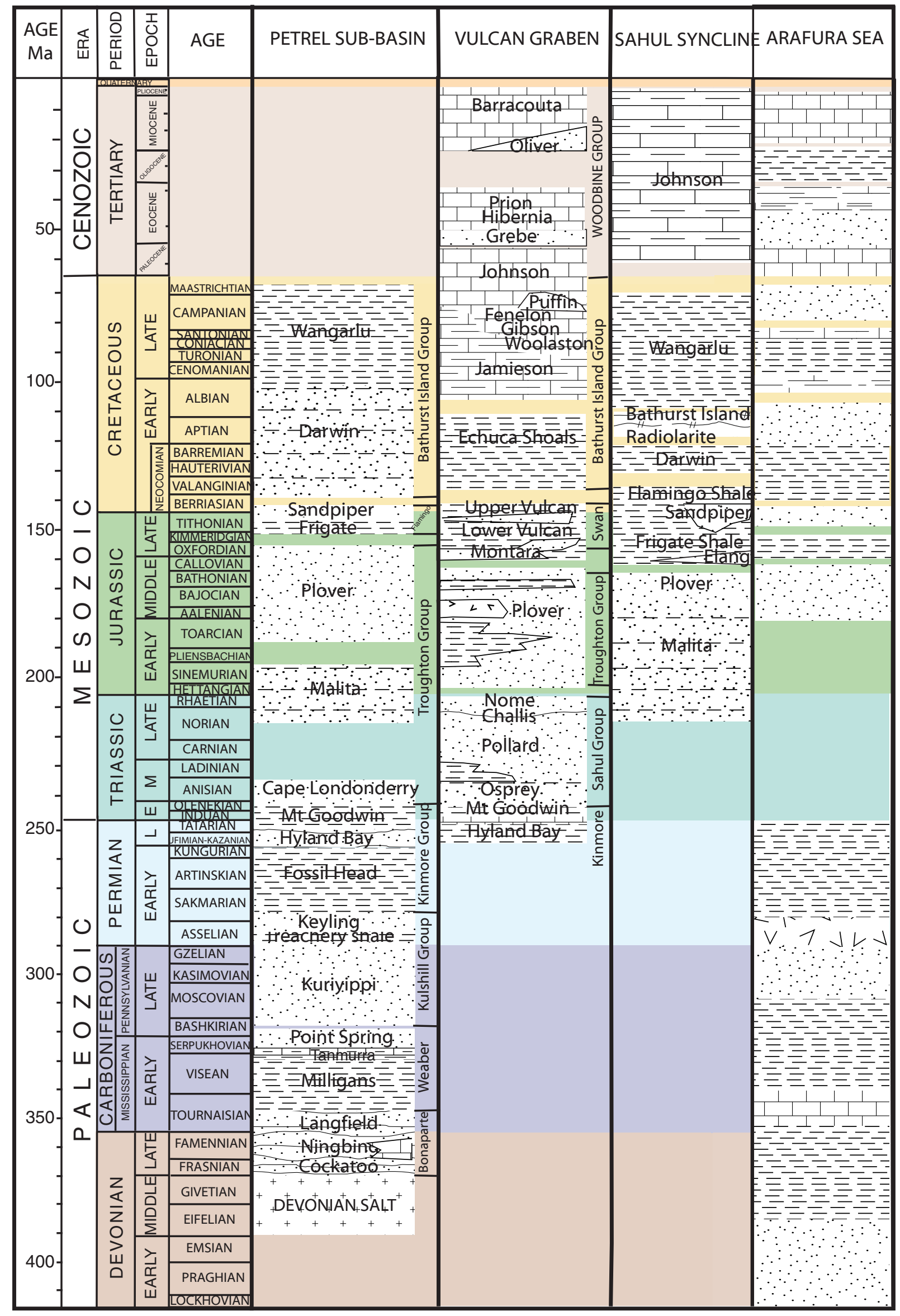

Figure 5. Correlation of generalized stratigraphy in four areas of province 3910. Based on stratigraphic terminology from DPIE, 1998; Brooks and others, 1996; Robinson and others, 1994; Young and others, 1995; Jefferies, 1988. Other authors describe the stratigraphy and age of bounderies differently, i.e. Cockatoo Gp, Ningbing Gp, Langfield Gp, Bonaparte Fm (Warris, 1993). 


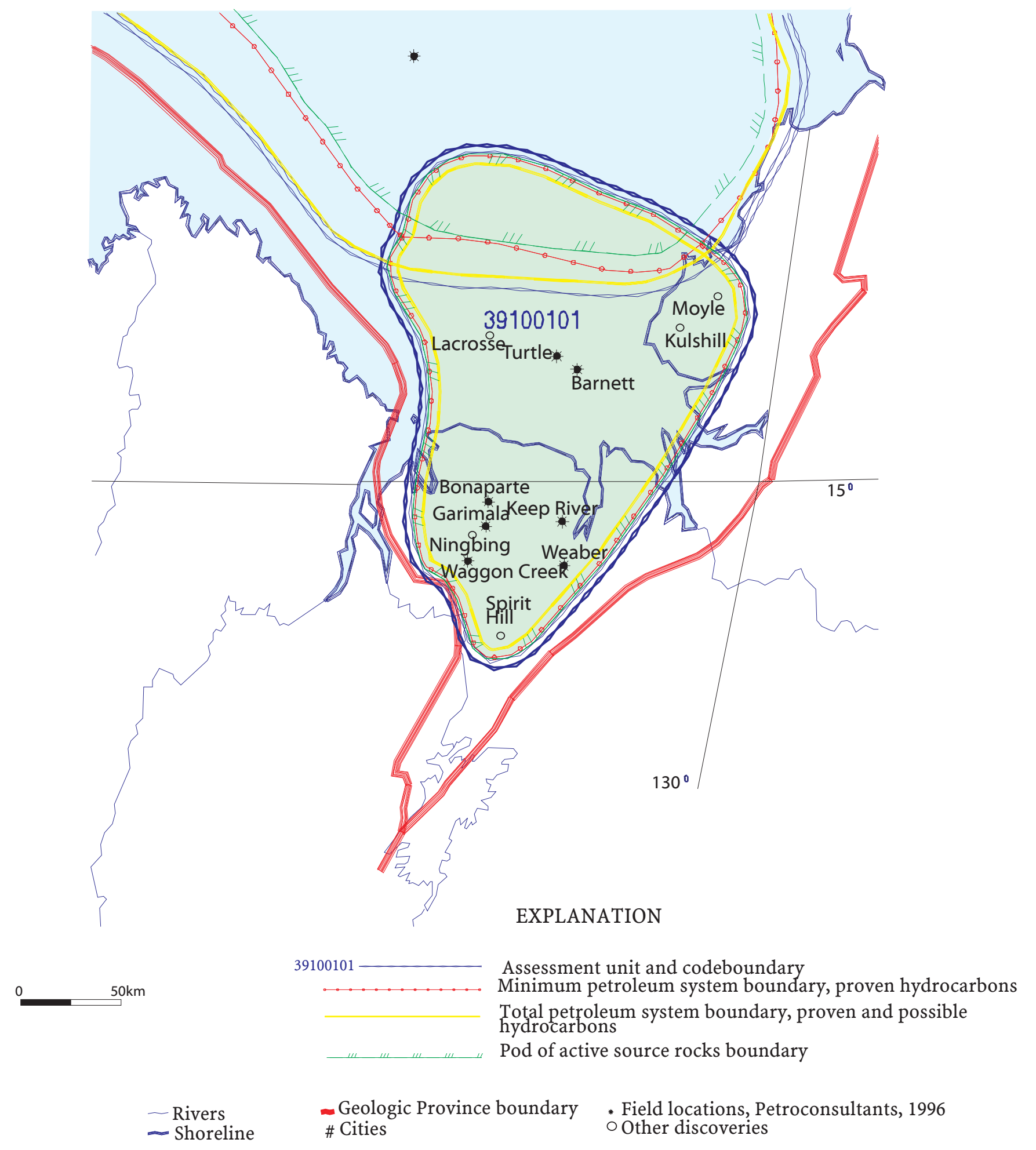

Figure 6. Index map of the Barnett assessment unit (39100101). The pod of active source rock is shown in green. Fields, as defined by Petroconsultants (1996), and other important discoveries in petroleum system 391001 are labeled. Information from Gunn, 1988b; DPIE, 1998. 


\begin{tabular}{|c|c|c|c|c|c|c|c|c|c|c|c|}
\hline 安 & 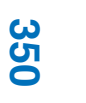 & $\stackrel{\omega}{\sigma}$ & & & $\tilde{\&}$ & $\bar{g}$ & & & 잉 & & GEOLOGIC \\
\hline 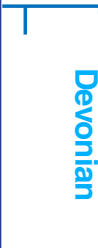 & 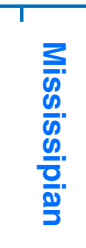 & 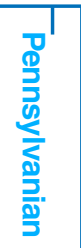 & 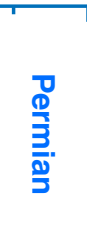 & 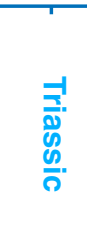 & & & & & 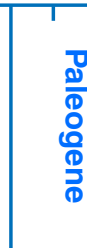 & $\begin{array}{l}z \\
0 \\
0 \\
0 \\
\overline{0} \\
\overline{0} \\
\overline{\bar{y}} \\
\overline{\overline{0}}\end{array}$ & SIME \\
\hline $\mathrm{m} 3$ & $\begin{array}{ll}m & r\end{array}$ & $\frac{\pi}{3} r$ & $\mathrm{~m}$ & $m_{3}$ & $\mathrm{~m}$ & 3 & $\mathrm{~m}$ & & $\begin{array}{ll}0 \\
0\end{array}$ & 3 & SYSTEM EVENTS \\
\hline & & & & & & & & & & & SOURCE ROCK \\
\hline & & & & & & & & & & & RESERVOIR ROCK \\
\hline & & & & & & & & & & & SEAL ROCK \\
\hline & & & & & & & & & & 口 & OVERBURDEN ROCK \\
\hline & 1 & t & & & & & & & & & TRAP FORMATION \\
\hline & & & & & & & & & & & GENERATION MGRATION CUMULATION \\
\hline & & & & & & & & & & & PRESERVATION \\
\hline & & & t & & & & & & & & CRITICAL MOMENT \\
\hline
\end{tabular}

Figure 7. Milligans-Carboniferous, Permian Total Petroleum System (391001) events chart, Bonaparte Gulf Province, Australia. 


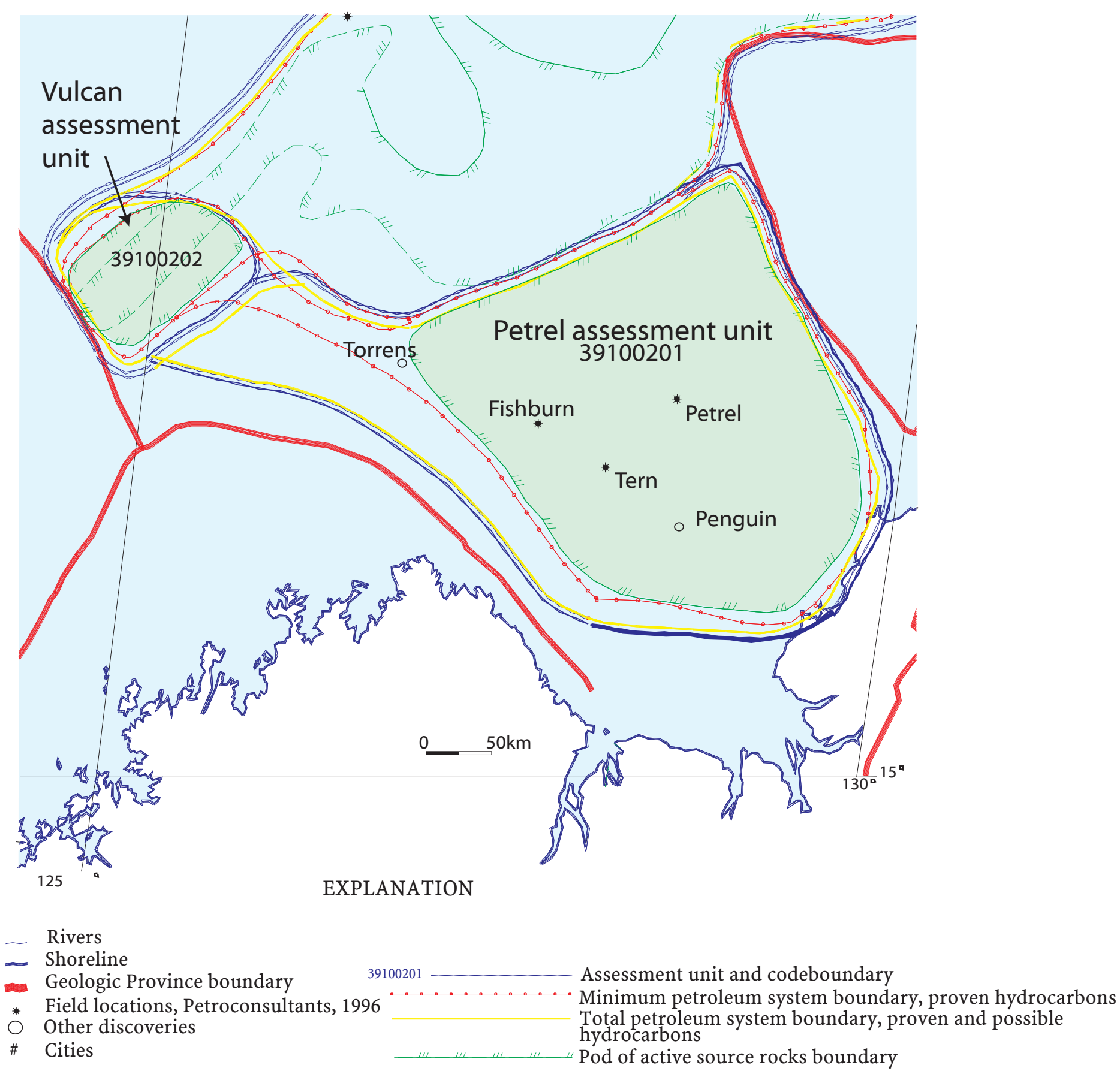

Figure 8. Index map of the Petrel assessment unit (39100201) and the Vulcan assessment unit (39100202). The pods of active source rock are shown. Important discoveries in petroleum system 391002 are labeled. DPIE, 1998. 


\begin{tabular}{|c|c|c|c|c|c|c|c|c|c|}
\hline$\stackrel{\omega}{\circ}$ & & N్ & 중 & $\vec{u}$ & & & जू & & \multirow{3}{*}{$\begin{array}{l}\text { GEOLOGIC } \\
\text { TIME } \\
\text { SCALE } \\
\text { SYSTETROLEUM EVENTS }\end{array}$} \\
\hline 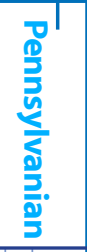 & $\begin{array}{l}\frac{70}{0} \\
\frac{1}{3} \\
\frac{3}{2} .\end{array}$ & 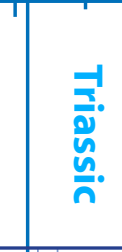 & \multicolumn{2}{|c|}{ 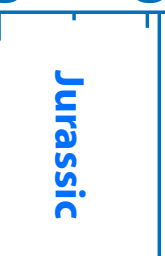 } & & & 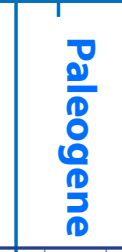 & $\begin{array}{l}z \\
0 \\
0 \\
0 \\
0 \\
0 \\
0 \\
0 \\
0 \\
0 \\
0 \\
0\end{array}$ & \\
\hline 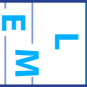 & $m$ & $\sqrt{1} r_{3}$ & $m$ & $3+$ & $\mathbf{m}$ & & 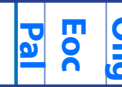 & & \\
\hline & & & & & & & & & SOURCE ROCK \\
\hline & & & & & & & & & RESERVOIR ROCK \\
\hline & & & & & & & & & SEAL ROCK \\
\hline & & & & & & & & & OVERBURDEN ROCK \\
\hline & & & & & & & & & TRAP FORMATION \\
\hline & & & & & & & & & $\begin{array}{l}\text { GENERATION MIGRATION ACCUMULATION } \\
\text { MEN }\end{array}$ \\
\hline & & & & & & & & & PRESERVATION \\
\hline 1 & & 0 & & & & & & & CRITICAL MOMENT \\
\hline
\end{tabular}

Figure 9. Keyling, Hyland Bay-Permian Total Petroleum System (391002) events chart, Bonaparte Basin Province, Australia. 


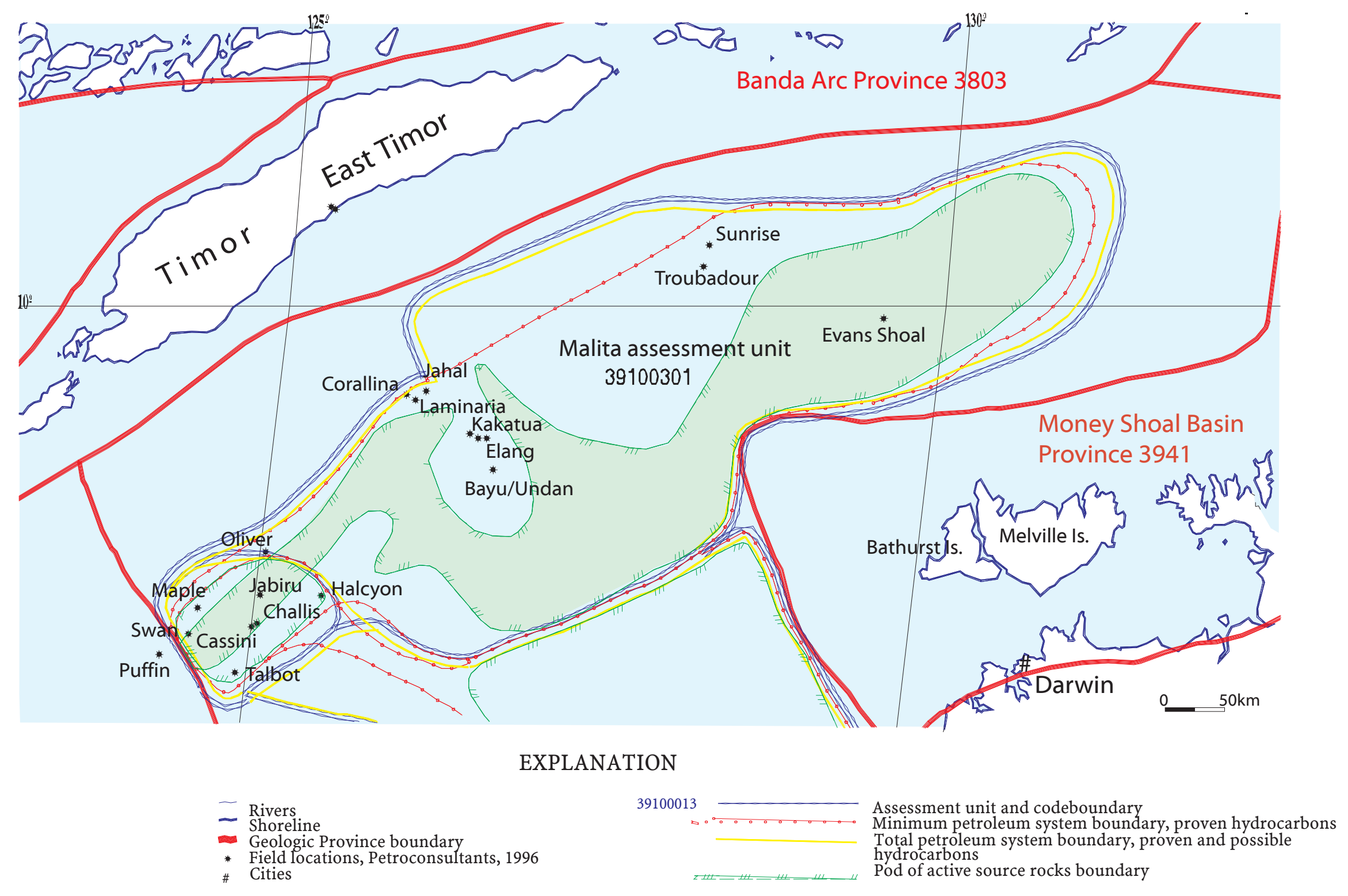

Figure 10. Index map of the Malita assessment unit (39100301). The pod of active source rock is shown in green. Important discoveries in petroleum system 391003 are labeled. Information from DPIE, 1998. 


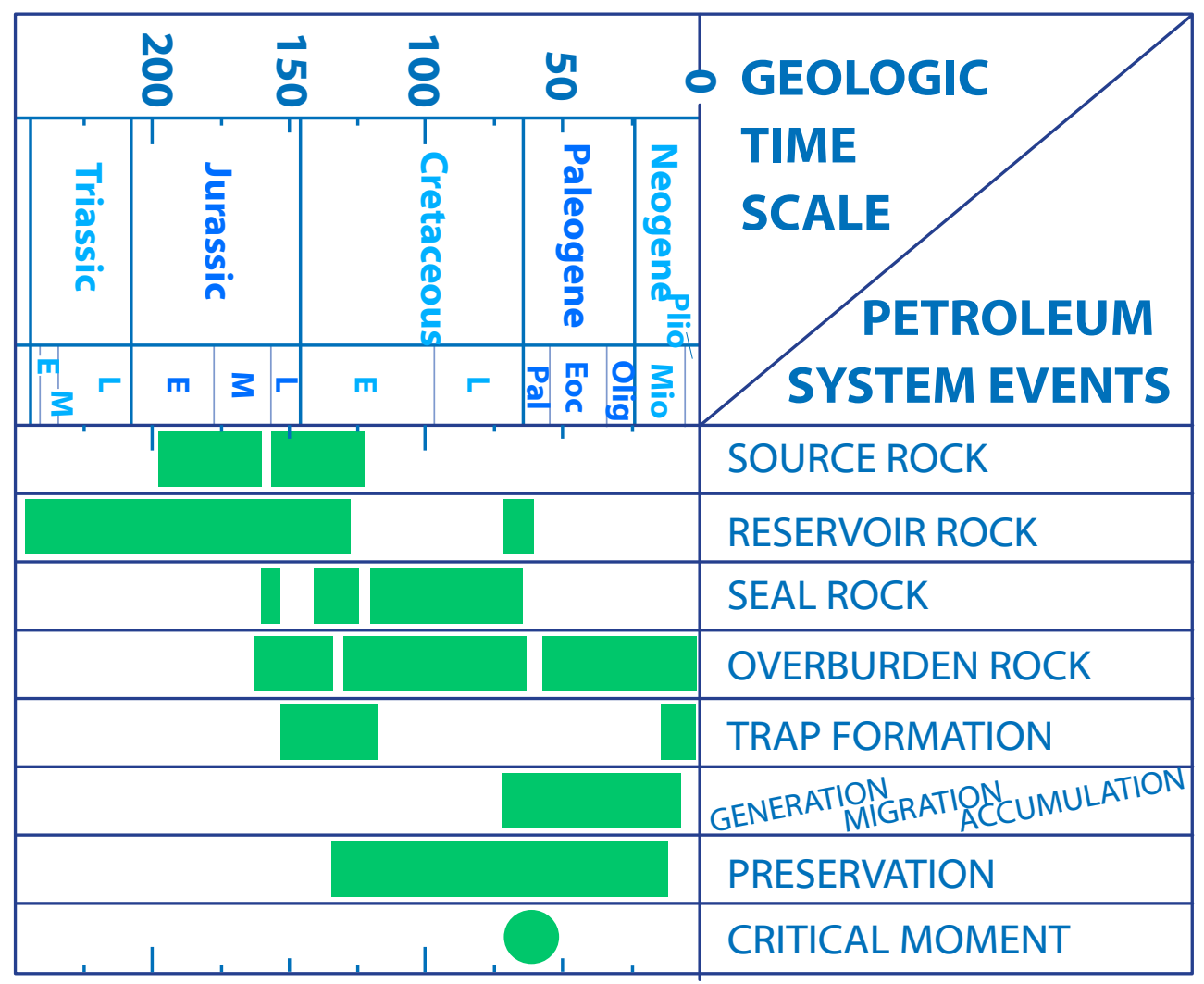

Figure 11. Jurassic, Early Cretaceous-Mesozoic Total Petroleum System (391003) events chart, Bonaparte Gulf Province, Australia. 